\title{
Identification, heterologous expression and characterization of a dye-decolorizing peroxidase of Pleurotus sapidus
}

\author{
Christiane Lauber ${ }^{1}$, Tatiana Schwarz², Quoc Khanh Nguyen², Patrick Lorenz ${ }^{2}$, Guenter Lochnit ${ }^{3}$ \\ and Holger Zorn ${ }^{1,4^{*}}$ (D)
}

\begin{abstract}
The coding sequence of a peroxidase from the secretome of Pleurotus sapidus was cloned from a cDNA library. Bioinformatic analyses revealed an open reading frame of $1551 \mathrm{bp}$ corresponding to a primary translation product of 516 amino acids. The DyP-type peroxidase was heterologously produced in Trichoderma reesei with an activity of $55,000 \cup \mathrm{L}^{-1}$. The enzyme was purified from the culture supernatant, biochemically characterized and the kinetic parameters were determined. The enzyme has an N-terminal signal peptide composed of 62 amino acids. Analysis by Blue Native PAGE and activity staining with ABTS, as well as gel filtration chromatography showed the native dimeric state of the enzyme $(115 \mathrm{kDa}$ ). Analysis of the substrate range revealed that the recombinant enzyme catalyzes, in addition to the conversion of some classic peroxidase substrates such as 2,2'-azino-bis(3-ethylthiazoline-6-sulfonate) and substituted phenols like 2,6-dimethoxyphenol, also the decolorization of the anthraquinonic dye Reactive Blue 5. The enzyme also catalyzes bleaching of natural colorants such as $\beta$-carotene and annatto. Surprisingly, $\beta$-carotene was transformed in the presence and absence of $\mathrm{H}_{2} \mathrm{O}_{2}$ by rPsaDyP, however enzyme activity was increased by the addition of $\mathrm{H}_{2} \mathrm{O}_{2}$. This indicates that the rPsaDyP has an oxidase function in addition to a peroxidase activity. As a consequence of the high affinity to the characteristic substrate Reactive Blue 5 the rPsaDyP belongs functionally to the dyp-type peroxidase family.
\end{abstract}

Keywords: Pleurotus sapidus, Dyp-type peroxidases, White rot, $\beta$-carotene, Anthraquinone dyes, Lignin degradation

\section{Introduction}

Heme peroxidases have been classified into various superfamilies according to their functional and structural properties (Morgenstern et al. 2008). According to the classification of Welinder (1992) DyP-type peroxidases were assigned to Class II of the plant-peroxidase superfamily. This class includes the secretory fungal peroxidases and is characterized by a wide homogeneity; for example the manganese peroxidases $(\mathrm{MnP})$, lignin peroxidases (LiP) and the versatile peroxidases (VP) all belong to this class (Lundell et al. 2010; Martínez 2002). All class II peroxidases are extracellular and contain heme as the

\footnotetext{
*Correspondence: holger.zorn@uni-giessen.de

${ }^{1}$ Institute of Food Chemistry and Food Biotechnology, Justus Liebig University Giessen, Heinrich-Buff-Ring 17, 35392 Giessen, Germany Full list of author information is available at the end of the article
}

prosthetic group (Poulos 2010; Welinder 1992). The DyPtype peroxidases, however, show no homology to any other known peroxidase families. They possess a unique characteristic that differentiates them from other heme peroxidases and thus they consequently form their own superfamily (EC 1.11.1.19) among the heme-peroxidases. Recently Zámocký et al. $(2009,2015)$ have suggested a new classification based on the overall fold, the structure of the active center and enzymatic activity. DyPtype peroxidases are now consequently allocated to the peroxidase-cyclooxygenase superfamily that is characterized by ferredoxin-like folding of the $\beta$-sheet structure and represents part of the very large $\alpha / \beta$-barrel structure superfamily. The first indication of the existence of this peroxidase type was discovered by Kim et al. (1995). The first enzyme of this family (Bad DyP) was extracted from 
the fungus Bjerkandera adusta and was consequently purified and characterized (Kim and Shoda 1999a). In the meantime DyP-type peroxidases have not only been discovered in Basidiomycota, but also in Ascomycetes and bacteria (Hofrichter et al. 2010). This also implies that these peroxidases have a common origin before the division of the domains (Sugano 2009). The classical DyP from Bjerkandera adusta is the most completely characterized member of the family of DyP-type peroxidases. The term dye decolorizing peroxidase "DyP" presently describes a more polyphyletic group of enzymes (Ahmad et al. 2011). A subdivision of the peroxidases into three groups (P, I, V) has recently been suggested for the classification of DyP-type peroxidases (Yoshida and Sugano 2015).

Ten DyP-type peroxidases from fungi have been thus far characterized, and only those from $B$. adusta und $A$. auricula-judae have been characterized from a structural and mechanical perspective (Linde and Coscolñas 2014; Linde et al. 2015a; Strittmatter et al. 2013; Sugano 2009; Yoshida et al. 2011, 2012). DyP-type peroxidases possess a unique $\mathrm{H}_{2} \mathrm{O}_{2}$-binding site that differs from those of other peroxidases (Sugano et al. 1999). Whereas in the enzymes of the superfamily of plant peroxidases the rearrangement of the protons of $\mathrm{H}_{2} \mathrm{O}_{2}$ is typically mediated by the distal histidine this is accomplished by an aspartate in DyP-type peroxidases (Sugano et al. 2007).

DyP-type peroxidases are catalytically very versatile and stable (Pühse et al. 2009). They possess a high redox potential $(1.1-1.2 \mathrm{~V})$ so that numerous substrates can serve as electron donors (Liers et al. 2013a). DyP-type peroxidases are therefore able to oxidize a wide spectrum of complex dyes, in particular xenobiotic anthraquinone derivatives as well as typical peroxidase substrates such as ABTS (2,2'-azino-bis(3-ethylthiazoline-6-sulfonate)) and phenols (Sugano 2009). Certain Dyp-type peroxidases cleave $\beta$-carotene and other carotenoids, non-phenolic bonds such as veratryl alcohol and the $\beta-O-4$ lignin model dimer adlerol (Liers et al. 2010).

Pleurotus sapidus is a Basidiomycete of the family Pleurotaceae (oyster mushrooms) belonging to the white-rot fungi. It grows on wood (pillar fungus). White-rot fungi are the most efficient lignin destruents and are able to fully decompose complex polymers (Rajarathnam et al. 1998). In addition, $P$. sapidus is able to decompose natural pigments such as $\beta$-carotene (Schüttmann et al. 2014). Numerous enzymes that are involved in lignocellulose decomposition have been identified in the secretome of $P$. sapidus. For example, the fungus secretes cellulases, hemicellulases, peptidases, esterases, laccases and in particular peroxidases into the culture medium (Zorn et al. 2005).
As a result of their wide substrate spectrum DyP-type peroxidases are interesting tools for biotechnological processes used in the decomposition of xenobiotic anthraquinone derivatives in sewage and soil (Husain 2006; Sugano et al. 2007) and are already finding use in the food industry. For example, the DyP-type peroxidase MsP1 from M. scorodonius (Scheibner et al. 2008), marketed as MaxiBright $^{\circledR}$ (DSM, Heerlen, the Netherlands), is used to whiten whey for cheese production. The enzyme thus represents an alternative to chemical bleaches (Szweda et al. 2013).

In the present report we publish a cDNA sequence that codes for a DyP-type peroxidase from Pleurotus sapidus. Only two reports have been published on the DyPs from Pleurotus fungi (Faraco et al. 2007; FernándezFueyo et al. 2015). The enzyme was efficiently expressed heterologously in Trichoderma reesei, purified and biochemically characterized. Homology studies allow the identification of important catalytic amino acids and potential substrate oxidation sites.

\section{Materials and methods Chemicals}

Chemicals and reagents used were obtained from Carl Roth (Karlsruhe, Germany), Sigma (Neu-Ulm, Germany) or Merck (Darmstadt, Germany). Chemicals and materials for electrophoresis were from Serva and Bio-Rad.

\section{Strains and culture methods}

Pleurotus sapidus (DSM 8266) was obtained from the German Collection of Microorganisms and Cell Cultures (DSMZ, Braunschweig, Germany). The Basidiomycete was cultivated in standard culture medium $\left(30 \mathrm{~g} \mathrm{~L}^{-1} \mathrm{D}-\right.$ (+)-glucose $\cdot \mathrm{H}_{2} \mathrm{O}, 4.5 \mathrm{~g} \mathrm{~L}^{-1}$ L-asparagine $\cdot \mathrm{H}_{2} \mathrm{O}, 1.5 \mathrm{~g} \mathrm{~L}-1$ $\mathrm{KH}_{2} \mathrm{PO}_{4}, 0.5 \mathrm{~g} \mathrm{~L}^{-1} \mathrm{MgSO}_{4} \cdot \mathrm{H}_{2} \mathrm{O}, 3.0 \mathrm{~g} \mathrm{~L}^{-1}$ yeast extract, $1 \mathrm{~mL} \mathrm{~L}^{-1}$ trace element solution: $5 \mathrm{mg} \mathrm{L}^{-1} \mathrm{CuSO}_{4} \cdot 5 \mathrm{H}_{2} \mathrm{O}$, $80 \mathrm{mg} \mathrm{L}{ }^{-1} \mathrm{FeCl}_{3} \cdot 6 \mathrm{H}_{2} \mathrm{O}, 90 \mathrm{mg} \mathrm{L} \mathrm{L}^{-1} \mathrm{ZnSO}_{4} \cdot 7 \mathrm{H}_{2} \mathrm{O}$, $30 \mathrm{mg} \mathrm{L}^{-1} \mathrm{MnSO}_{4} \cdot \mathrm{H}_{2} \mathrm{O}$, and $0.4 \mathrm{~g} \mathrm{~L}^{-1}$ EDTA; $\mathrm{pH}$ 6.0) for 10 days $\left(24^{\circ} \mathrm{C}, 150 \mathrm{rpm}, 25 \mathrm{~mm}\right.$ shaking diameter).

Escherichia coli (TOP10) was obtained from Invitrogen (Karlsruhe, Germany) and was used for vector propagation. TSS competent cells were transformed by heat shock treatment $\left(2 \mathrm{~min}, 42^{\circ} \mathrm{C}\right)$ according to the standard protocols. Recombinant cells were cultivated in sterile LB medium $\left(10 \mathrm{~g} \mathrm{~L}^{-1}\right.$ tryptone, $5 \mathrm{~g} \mathrm{~L}^{-1}$ yeast extract, $10 \mathrm{~g} \mathrm{~L}^{-1} \mathrm{NaCl}$ ) with $150 \mathrm{mg} \mathrm{L}^{-1}$ ampicillin used as selection marker $\left(37^{\circ} \mathrm{C}, 225 \mathrm{rpm}\right)$.

\section{cDNA-synthesis}

To isolate the RNA the mycelium of a $P$. sapidus submersion culture was harvested on culture day 5 and 100 mg was disintegrated by grinding in liquid nitrogen. 
Isolation of the total RNA was performed with RNeasy ${ }^{\mathrm{TM}}$ Plant Mini Kits (Qiagen, Hilden, Germany) according to the manufacturer's instructions. The quality of the RNA was verified by agarose electrophoresis and ethidium bromide staining. A cDNA library of $P$. sapidus was produced using the isolated RNA as template. cDNA synthesis was performed with help of the SMART ${ }^{\mathrm{TM}}$ PCR cDNA Synthesis Kits (Clontech Laboratories Inc., SaintGermain-en-Laye, France). SuperScript ${ }^{\circledR}$ II Reverse Transcriptase (Invitrogen, Darmstadt, Germany) was used for first-strand synthesis. Amplification of a coding DyP-type peroxidase sequence of P. sapidus from the cDNA library was performed by PCR. The primers DTP_for58 (5'-ATGCGCTGGTGGACTACC-3') and DTP_rev54 (5'-TTAAGCAGCGATTTTGTGC-3') were derived from a homologous Dyp-type peroxidase sequence from the genome (DOE-JGI) of Pleurotus ostreatus. Amplification of the specific cDNA occurred in an Alpha SC PCR Thermocycler (Analytik Jena, Jena, Germany). The following PCR protocol was followed: $50 \mathrm{ng}$ template, $5 \times$ PCR-Puffer including dNTP's (Qiagen), forward and reverse primer 50 pmol, $1.25 \mathrm{U}$ HotStar HiFidelity DNA-Polymerase (Qiagen) $\mathrm{ddH}_{2} \mathrm{O}$ ad $50 \mu \mathrm{L}, 95{ }^{\circ} \mathrm{C} 5 \mathrm{~min}-95{ }^{\circ} \mathrm{C} 1 \mathrm{~min}, 51{ }^{\circ} \mathrm{C} 1 \mathrm{~min}, 72{ }^{\circ} \mathrm{C}$ $2 \mathrm{~min}, 40$ cycles $-72{ }^{\circ} \mathrm{C} 5 \mathrm{~min}$. PCR products were separated electrophoretically $(1.2 \%(\mathrm{w} / \mathrm{v})$ agarose gel), subsequently isolated from the gel using NucleoSpin Extract II-Kits (Machery-Nagel, Düren, Germany) and finally ligated (Topo TA-Cloning ${ }^{\circledR}$ Kit, Invitrogen) in the vector pCR2.1-TOPO ${ }^{\circledR}$ (Invitrogen). The plasmid DNA was replicated in $E$. coli TOP10 cells (Invitrogen), isolated from the cells and purified (NucleoSpin ${ }^{\circledR}$ Plasmid DNA Purification, Machery-Nagel). Sequencing of the cloned cDNA was performed by MWG Eurofins (Ebersberg, Germany).

\section{Enzyme production}

For recombinant production of the peroxidase the codon usage of the gene was adapted to the host organism Trichoderma reesei (a derivative of RUT C30; Peterson and Nevalainen 2012) and an expression cassette was constructed from the adapted sequence. The expression of peroxidase took place under the control of the cbhl promotor and terminator. Efficient production of the peroxidase was achieved by optimization of the fermentation process under fed-batch conditions (pH5.5, $28{ }^{\circ} \mathrm{C}$, $160 \mathrm{~h}$ ) in Monosaccharide medium (7\% monosaccharide, $4 \%$ agricultural waste stream derived $\mathrm{N}$-source, $0.7 \%$ $\left.\left(\mathrm{NH}_{4}\right)_{2} \mathrm{SO}_{4}, 0.3 \% \mathrm{KH}_{2} \mathrm{PO}_{4}\right)$.

\section{Determination of enzyme activity}

Enzyme activity was determined photometrically using a temperature controlled multi-mode plate reader (Synergy
TM 2, BioTek Instruments GmbH, Bad Friedrichshall, Germany) or alternatively in a UV/Vis spectrophotometer (SPECORD ${ }^{\circledR} 50$, Analytik Jena AG, Jena, Germany). Reactions were initiated by addition of the enzyme. Enzyme activity was measured over a period of $10 \mathrm{~min}$ at $25{ }^{\circ} \mathrm{C}$ at the appropriate wavelength for the substrate. One unit $(1 \mathrm{U})$ is defined as the amount of enzyme that converts $1 \mu \mathrm{mol}$ substrate per minute. Various $\mathrm{H}_{2} \mathrm{O}_{2}$ concentrations $(0-1250 \mu \mathrm{M}$, enzyme concentrations $(0.27-54 \mathrm{nM})$ and substrate concentrations were used to determine the enzyme activity.

The activity of rPsaDyP vs ABTS was determined in $100 \mathrm{mM}$ sodium acetate buffer at $\mathrm{pH} 3.8$ and a final $\mathrm{H}_{2} \mathrm{O}_{2}$ concentration of $125 \mu \mathrm{M}$. Production of the ABTS cation radical was studied according to Eggert et al. (1996) at $420 \mathrm{~nm}\left(\varepsilon_{420} 36,000 \mathrm{~L} \mathrm{~mol}^{-1} \mathrm{~cm}^{-1}\right)$.

Oxidation of DMP and guaiacol was followed in $50 \mathrm{mM}$ sodium acetate buffer at $\mathrm{pH} 4.5$ at a final $\mathrm{H}_{2} \mathrm{O}_{2}$ concentration of $62.5 \mu \mathrm{M}$ as based on the formation of the dimeric quinone derivate at $469 \mathrm{~nm}\left(\varepsilon_{469}\right.$ $27,500 \mathrm{~L} \mathrm{~mol}^{-1} \mathrm{~cm}^{-1}$ referred to the substrate) according to Saparrat et al. (2002) or tetraguaiacol at $470 \mathrm{~nm}$ $\left(\varepsilon_{470} 26,600 \mathrm{~L} \mathrm{~mol}^{-1} \mathrm{~cm}^{-1}\right)$ according to Koduri and Tien (1995).

Oxidation of Reactive Blue 5 dye (Rblue 5) was performed in $100 \mathrm{mM}$ sodium acetate buffer at $\mathrm{pH} 4.0$ and a final $\mathrm{H}_{2} \mathrm{O}_{2}$ concentration of $31.2 \mu \mathrm{M}$. Degradation of the substrate was determined at $600 \mathrm{~nm}\left(\varepsilon_{600}\right.$ $8000 \mathrm{~L} \mathrm{~mol}^{-1} \mathrm{~cm}^{-1}$ ) according to Sugano et al. (2006).

Oxidation of the azo dye Reactive Black 5 (RBlack 5) was determined in $50 \mathrm{mM}$ sodium acetate buffer at $\mathrm{pH} 4.0$ with $62.5 \mu \mathrm{M} \mathrm{H}_{2} \mathrm{O}_{2}$ at $598 \mathrm{~nm}\left(\varepsilon_{598} 37,200 \mathrm{~L} \mathrm{~mol}^{-1} \mathrm{~cm}^{-1}\right)$ according to Sugano et al. (2006).

A $\beta$-carotene stock solution was prepared as described by Pühse et al. (2009). Measurement of the substrate degradation was performed at $450 \mathrm{~nm}\left(\varepsilon_{450} \quad 95,000\right.$

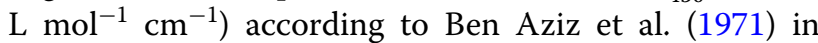
$50 \mathrm{mM}$ sodium acetate buffer at $\mathrm{pH} 3.5$ with a final $\mathrm{H}_{2} \mathrm{O}_{2}$ concentration of $125 \mu \mathrm{M}$. To assess the purified enzyme's oxygenase activity in the absence of $\mathrm{H}_{2} \mathrm{O}_{2}, 100 \mathrm{~mL}$ sodium acetate buffer (100 mM, pH 3.8) was purged with oxygen through a glass frit (pore size 3, pore diameter $16-40 \mu \mathrm{m})$ for $30 \mathrm{~min}$. For control experiments in the absence of $\mathrm{H}_{2} \mathrm{O}_{2}$ and oxygen, $100 \mathrm{~mL}$ of the buffer was sonicated for $60 \mathrm{~min}$, and residual oxygen was removed by purging with nitrogen. The assays were performed with enzyme concentrations of 270, 360, and $540 \mathrm{nM}$, and the concentration of the substrate was $26 \mu \mathrm{M}$.

As further examples of natural dyes annatto (aqueous alkaline extract), the principle component of which is norbixin, and bixin were used as substrates. Preparation of the bixin stock solution was analogous to that of $\beta$-carotene (using $15 \mathrm{mg}$ bixin). Conversions took place 
in $50 \mathrm{mM}$ sodium acetate buffer at $\mathrm{pH} 6.0$ or 3.5 with a final $\mathrm{H}_{2} \mathrm{O}_{2}$ concentration of $125 \mu \mathrm{M}$. Degradation of the dye was observed at $452 \mathrm{~nm}\left(\varepsilon_{452} 108,400 \mathrm{~L} \mathrm{~mol}^{-1} \mathrm{~cm}^{-1}\right.$, Scotter et al. 1998) or $465 \mathrm{~nm}\left(\varepsilon_{465} 136,100 \mathrm{~L} \mathrm{~mol}^{-1} \mathrm{~cm}^{-1}\right.$, Hülsdau 2007).

Samples of heat inactivated $\left(95{ }^{\circ} \mathrm{C}, 10 \mathrm{~min}\right)$ enzyme served as negative controls.

\section{Purification of the DyP-type peroxidase by fast protein liquid chromatography (FPLC)}

Purification was carried out in a cold room at $4{ }^{\circ} \mathrm{C}$. Chromatographic separation of the proteins was performed using a BioLogic DuoFlow ${ }^{\text {TM }}$ (Biorad) FPLC-System with fraction collector (BioLogic BioFrac ${ }^{\mathrm{TM}}$ fraction collector, Biorad). Proteins were detected at $280 \mathrm{~nm}$. The DyP-type peroxidase was purified in a two-stage process by hydrophobic interaction chromatography and ion exchange chromatography. The culture supernatant was concentrated (Macrosep ${ }^{\circledR}, 10 \mathrm{kDa}$ cutoff, Pall, Dreieich, Germany) and transferred to $50 \mathrm{mM}$ sodium acetate buffer at $\mathrm{pH} 4.0$ with $1 \mathrm{M}\left(\mathrm{NH}_{4}\right)_{2} \mathrm{SO}_{4}$. In the first stage the concentrated culture supernatant was purified on a column with phenyl-Sepharose-matrix (HiPrep Phenyl FF (high sub) 16/10, GE Healthcare Bio-Sciences AB, Uppsala, Sweden). The Starting buffer used was $50 \mathrm{mM}$ sodium acetate buffer $\mathrm{pH} 4.0$ with $1 \mathrm{M}\left(\mathrm{NH}_{4}\right)_{2} \mathrm{SO}_{4}$ and proteins were eluted over a gradient of 0 to $58 \%(40 \mathrm{~mL})$ and from 58 to $100 \%(30 \mathrm{~mL})$ sodium acetate buffer $\mathrm{pH} 4.0$. Flow rate was $3 \mathrm{~mL} \mathrm{~min}{ }^{-1}$ and fractions with a volume of $2 \mathrm{~mL}$ were collected. Protein containing fractions were tested and active fractions pooled for the second purification step. They were then concentrated, transferred to $50 \mathrm{mM}$ sodium acetate buffer $\mathrm{pH} 4.0$ and loaded onto a column with SP Sepharose Fast Flow Matrix (XK16/20, $25 \mathrm{~mL}$ column volume, GE Healthcare Bio-Sciences AB). Elution was performed on a gradient of $0-10 \%(30 \mathrm{~mL})$ and from 10 to $100 \%(30 \mathrm{~mL}) 50 \mathrm{mM}$ sodium acetate buffer $\mathrm{pH} 4.0$ with $1 \mathrm{M} \mathrm{NaCl}$ at a flow rate of $3 \mathrm{~mL} \mathrm{~min}^{-1}$. Active fractions of the second purification stage were pooled, concentrated, aliquoted, shock frozen in liquid nitrogen and stored at $-80^{\circ} \mathrm{C}$.

\section{Enzyme characterization}

Protein concentration was determined according to Bradford (1976) using the dye solution Roti ${ }^{\circledR}$ Nanoquant (Roth, Karlsruhe, Germany) with bovine serum albumin or lyophilized DyP as standard.

$\mathrm{UV} / \mathrm{Vis}$ spectra of the purified $\mathrm{rPsaDyP}$ were recorded at $250 \mathrm{~nm}$ to $800 \mathrm{~nm}$ in a NanoPhotometer (Pearl, Implen $\mathrm{GmbH}$, Munich, Deutschland).

Molecular mass determination of the DyP-type peroxidase was performed using SDS-PAGE (Mini-Protean ${ }^{\circledR}$ TetraSystem, BioRad) according to Laemmli. Separation of the proteins took place in a $6 \%$ stacking and a $12 \%$ separation gel. Protein bands were visualized using colloidal Coomassie staining (Kang et al. 2002). Size determination was performed with the help of PageRuler ${ }^{\mathrm{TM}}$ Unstained Proteinladder (Fermentas, St. Leon-Rot, Germany). For $\mathrm{N}$-deglycosylation samples were incubated with PNGase F (NEB, Ipswich, USA) and treated following the manufacturer's instructions.

The size of the native proteins was determined by gel filtration chromatography (GFC) and Blue Native PAGE. For GFC the protein was loaded onto a Superdex 200 10/300 GL column (GE Healthcare) and eluted with a $50 \mathrm{mM}$ sodium acetate buffer $\mathrm{pH} 4.0$ with $250 \mathrm{mM}$ $\mathrm{NaCl}$ and $0.005 \%$ Triton $\mathrm{X}-100$ at a flow rate of $0.5 \mathrm{~mL}$ $\mathrm{min}^{-1}$. For Blue Native PAGE precast gels from Serva (SERVAGel $^{\mathrm{TM}}$ N Native Starter Kit, Serva, Heidelberg, Germany) and the PerfectBlue ${ }^{\circledR}$ Double Gel System Twin $S$ of Peqlab were used. For isoelectric focusing (IEF) the same electrophoresis system was used (precast vertical gels and IEF marker 3-10, Liquid Mix, Serva). Visualization of the protein bands was performed as described above. In addition, specific staining of heme- and metal enzymes was performed with 3,3',5,5'-tetramethylbenzidine (TMB) $\left(1.5 \mathrm{mg} \mathrm{mL}^{-1}\right.$ in methanol) modified according to Thomas et al. (1976) and Henne et al. (2001). Native electrophoresis was followed by activity staining with ABTS as substrate. For this the gel was equilibrated for $5 \mathrm{~min}$ in $100 \mathrm{~mL}$ freshly prepared stain solution (5 mM ABTS in $50 \mathrm{mM}$ sodium acetate $\mathrm{pH} 4.0$ ) on an orbital shaker. Subsequently, $150 \mu \mathrm{L} 3 \% \mathrm{H}_{2} \mathrm{O}_{2}$ (final concentration $130 \mu \mathrm{M}$ ) was added and shaking continued until a distinct staining was obtained. Gels were then rinsed with pure water and documented.

\section{Influence of $\mathrm{pH}$ value}

The optimum $\mathrm{pH}$ of the purified $\mathrm{rPsaDyP}$ was determined in Mcllvaine-Puffer (pH 2.2-7.5, Mcllvaine, 1921), $50 \mathrm{mM}$ sodium acetate buffer $(\mathrm{pH} 3.0-6.0)$ and $100 \mathrm{mM}$ sodium tartrate buffer $(\mathrm{pH} 2.0-5.5)$ with ABTS as substrate. The $\mathrm{pH}$ stability was determined by diluting the DyP-type peroxidase in sodium acetate buffer at a $\mathrm{pH}$ range of $3.0-6.0$ (0.5 steps). To avoid altering the $\mathrm{pH}$ value too drastically for the measurement the samples were again diluted 1:10 with $100 \mathrm{mM}$ sodium acetate buffer pH 3.8 (measurement buffer). Rest activity was measured after $0.5,1,2$ and $24 \mathrm{~h}$ storage at $4{ }^{\circ} \mathrm{C}$ using ABTS as substrate and values were compared to the initial activity.

\section{Effect of temperature}

To determine the optimum $\mathrm{pH}$ for the purified $\mathrm{rPsaDyP}$ the enzyme was initially incubated for $4 \mathrm{~min}$ in $50 \mathrm{mM}$ sodium acetate buffer at $\mathrm{pH} 3.8$ at various temperatures 
$\left(15-75{ }^{\circ} \mathrm{C}\right)$. The rate of turnover was then measured at the corresponding temperature in a photometer with temperature regulated cuvette.

\section{Determination of kinetic parameters}

The apparent value of the Michaelis-Menten constant $\left(K_{m}\right)$ and catalytic constant $\left(k_{\text {cat }}\right)$ of the purified rPsaDyP were determined for ABTS, DMP, guaiacol and RBlue 5. Substrate turnover took place at $30^{\circ} \mathrm{C}$ in 6 replicate preparations. The initial rate was determined with constant enzyme concentration, varying substrate concentrations and constant cosubstrate concentration. Measurements were taken in parallel with varying $\mathrm{H}_{2} \mathrm{O}_{2}$ concentrations in order to determine the $\mathrm{H}_{2} \mathrm{O}_{2}$ concentration that no longer had a limiting effect on the activity. The following substrate concentrations were chosen for determination of the kinetic parameters: ABTS 15-1500 $\mu \mathrm{M}$, DMP 250-15,000 $\mu \mathrm{M}$, guaiacol 500-15,000 $\mu \mathrm{M}$, RBlue 5 11-300 $\mu \mathrm{M}$. The initial rate $\left(v_{0}\right)$ was plotted linear to the substrate concentration in a graph (Cornish-Bowden diagram). Using the software Origin (OriginPro 8.6G) a saturation hyperbola was adapted through a non-linear regression in order to obtain values for $K_{m}$ and $v_{\max }$. The catalytic constant $k_{\text {cat }}$ was determined using the following equation, whereby $\mathrm{E}$ represents the enzyme concentration applied:

$$
k_{c a t}=\frac{v_{\max }}{[E]}
$$

\section{Results}

\section{Identification of the coding sequence of DyP-type peroxidase}

The 1551 bp full-length cDNA of a DyP-type peroxidase gene of Pleurotus sapidus (strain 8266) was amplified. This gene codes for a protein of 516 AA (Fig. 1, Accession Number LN830264), a theoretical molecular weight of $57.1 \mathrm{kDa}$ and a calculated isoelectric point (pl) of 5.73 (ExPASy ProtParam). The ORF exhibits 4 potential $N$-glycosylation sites and a potential $O$-glycosylation site (NetNGly 1.0, NetOGly3.1).

With the identification of putative conserved domains the enzyme is assigned to the dye decolorizing peroxidase superfamily (EMBL-EBI, InterProScan). In addition, the structural motif GxxDG that is present in all members of the DyP-type peroxidase family was found in the sequence. The translated amino acid sequence shows a high degree of identity (95\%) to a DyP-type peroxidase from Pleurotus ostreatus (ID EMBL CAK55151.1). Furthermore, the amino acid sequence exhibits an identity of 42-43\% with DyP-type peroxidases from B. adusta (Accession Number: BAA77283.1), M. scorodonius (Accession Number: B0BK71.1) and A. auricula-judae (Accession Number: AFJ79723).

\section{Structure and sequence based analysis}

A structural homology model of the DyP-type peroxidase from $P$. sapidus was calculated based on the x-ray crystal structure of DyP-type peroxidase from A. auricula-judae (PDB-ID 4AU9B). The structures exhibit a homology of $44 \%$.

The calculated structural model possesses a helical basic structure with two domains (proximal N-terminal, distal C-terminal domains), that enclose the central cofactor heme. A prominent motif made up of anti-parallel $\beta$-sheet structures that, together with the $\alpha$-helices, exhibit a ferredoxin-like folding is present on the distal side of the heme. With the help of this structure homology model it was possible to identify important functional amino acid residues (Fig. 2). The access channel to the heme of the catalytic channel forms a predominantly hydrophobic channel through which the substrate reaches the $\mathrm{H}_{2} \mathrm{O}_{2}$ binding pocket (Yoshida et al. 2011). Three of the remaining residues of the $\mathrm{H}_{2} \mathrm{O}_{2}$ binding pocket are also conserved in rPsaDyP, whereby in the DyP-type peroxidases from $P$. sapidus and P. ostreatus leucine is exchanged for valine (rPsaDyPV363). The catalytic residues of D174-part of the conserved GxxDG motif-and R338 on the proximal side H317 as fifth ligand of heme were identified. These residues are involved in the activation of the enzyme (formation of compound I) by heterolytic cleavage of $\mathrm{H}_{2} \mathrm{O}_{2}$. Based on the alignment (Fig. 2) it was shown that E391, which forms a hydrogen bond with the fifth ligand of heme (H317), thus stabilizing compound I (Sugano et al. 2007), is exchanged for an aspartate (rPsaDyP D401) in other Dyp-type peroxidases. The arginine 267 and 324 hydrogen bonds with the propionate residues of the heme form additional ligands. The conserved amino acid residues Y343 and W383 that were exposed to the solvent are found on the surface. These serve as oxidation sites for large substrates and may be elements of a LRET (long range electron transfer) (Liers et al. 2013a; Strittmatter et al. 2013).

\section{Heterologous expression and purification}

For purification and characterization peroxidase positive transformants were cultivated in large scale (XL) under conditions that yield active protein in the culture supernatant. After $160 \mathrm{~h}$ cultivation an activity of 55,000 $\mathrm{U} \mathrm{L}^{-1}$ in relation to the substrate ABTS was achieved and the supernatant containing the peroxidase was harvested. After concentration of the culture supernatant (crude enzyme) by a factor of 5 the Dyp-type peroxidase was purified in a two-stage sequential procedure using FPLC with hydrophobic interaction chromatography and ion exchange chromatography. The DyP-type peroxidase was purified to apparent homogeneity. After the second 
ATGCGCTGGT GGACTACCTG CGTCGCTCTC ACTTCGTTAA TACCTTACGC CCTCTTGCCC $\begin{array}{lllllllllllllllllllllll}M & \mathrm{R} & \mathrm{W} & \mathrm{W} & \mathrm{T} & \mathrm{T} & \mathrm{C} & \mathrm{V} & \mathrm{A} & \mathrm{L} & \mathrm{T} & \mathrm{S} & \mathrm{L} & \mathrm{I} & \mathrm{P} & \mathrm{Y} & \mathrm{A} & \mathrm{L} & \mathrm{L} & \mathrm{P}\end{array}$

AGTTATGGGT TCAATCTGCC TCAGCAACTC GAGGCGAGGC AGAACGACTA TCCGAGTGGA 120

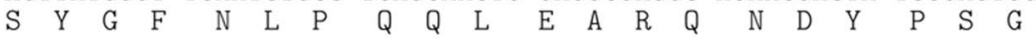
TCCCTACTAC ACGACTATCC TGGGCAGCAT ACATTGCCAA CGCTTGAGTT GATCCAGAAG 180

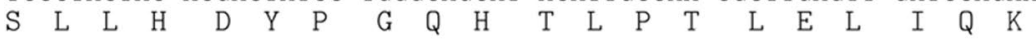

TTGAATGCCA CTAATGGCAC ATTCCTGCCG CTGGAagAGA TTCAAGGAGA TATTATGATT 240

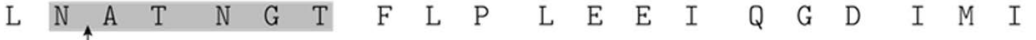
GGCATGAGGA AGCCCAAAGA AATCTTCTTT TTCTACTCGC TTCAGAATCC AAGGAAGTTC 300 $\begin{array}{lllllllllllllllllllll}G & M & R & K & P & K & E & I & F & F & F & Y & S & L & Q & N & P & R & K & F\end{array}$ AAGAGTGTCC TCGCGAAATT GATATACCCT CACATAACTA CGACTGCTCA AATGGTCTGC 360 $\begin{array}{llllllllllllllllllllllll}K & S & V & L & A & K & L & I & Y & P & H & I & T & T & T & A & Q & M & V & C\end{array}$ ACCACCTGCG CGCAACCCTC AGCTATGCTG AACGTCGCTT GGACTTCCCA AGGGTTGCGT 420

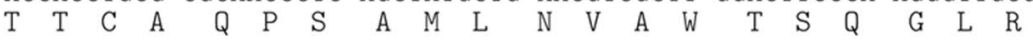
AAGCTCGGCG TCTTAGATAA CCTCGGTGAT CCCTACTTCG CTATGGGGCA ATTAAGCGAC 480 $\begin{array}{lllllllllllllllllllll}K & L & G & V & \text { L } & D & N & \text { L } & G & D & \text { P } & \text { Y } & \text { F } & \text { A } & \text { M } & G & \text { Q } & \text { L } & \text { S } & \text { D }\end{array}$ GCTGCCGCGC TTGGTGATAC CGACCCAAGC ACAACTTGGG CCCCAGGTCT CTACGCCAAC 540

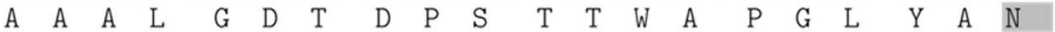
AAGACGGACG GCGCATTCCT CATCGCGGCT AAAGACTGGG AACCCATCGA CACCTTACTT 600 $\begin{array}{llllllllllllllllllll}\mathrm{K} & \mathrm{T} & \mathrm{D} & \mathrm{G} & \mathrm{A} & \mathrm{F} & \mathrm{L} & \mathrm{I} & \mathrm{A} & \mathrm{A} & \mathrm{K} & \mathrm{D} & \mathrm{W} & \mathrm{E} & \mathrm{P} & \mathrm{I} & \mathrm{D} & \mathrm{T} & \mathrm{L} & \mathrm{L}\end{array}$ AATCAAATGA AGGCCTGGTT GGGTGATGCG ATCGTAGAGA CACACAGCAA CAGGGGCGCA 660 $\begin{array}{llllllllllllllllllll}N & Q & M & K & A & W & L & G & D & A & \text { I } & V & E & T & H & S & N & R & G & A\end{array}$ GTACGACCTG GCGATGCAGC TGGTAAAGAG CACTTTGGCT GGCTTGATGG CTTTATTCAA 720 $\begin{array}{lllllllllllllllllllll}V & R & P & G & \text { D } & \text { A } & \text { A } & \text { G } & \text { K } & \text { E } & \text { H } & \text { F } & \text { G } & \text { W } & \text { L } & \text { D } & \text { G } & \text { F } & \text { I } & \text { Q }\end{array}$ CCTGCTGTAG CTGGCTTTGC TACAAGCACA TATCCCGGAC AGCAGCTCCT CCTACCCGGT 780 $\begin{array}{llllllllllllllllllll}P & A & V & A & G & F & A & \text { T } & \text { S } & \text { T } & \text { Y } & \text { P } & G & \text { Q } & \text { Q } & \text { L } & \text { L } & \text { L } & \text { P } & \text { G }\end{array}$ ACGCTTTTGA CGAAGGAAAT CGGCGACCCT CGCAGAGCTG CCCGACCAGC ATGGACGAAA 840 $\begin{array}{llllllllllllllllllll}\mathrm{T} & \mathrm{L} & \mathrm{L} & \mathrm{T} & \mathrm{K} & \mathrm{E} & \mathrm{I} & \mathrm{G} & \mathrm{D} & \mathrm{P} & \mathrm{R} & \mathrm{R} & \mathrm{A} & \mathrm{A} & \mathrm{R} & \mathrm{P} & \mathrm{A} & \mathrm{W} & \mathrm{T} & \mathrm{K}\end{array}$ TGGGGTTCCT TCATGGCTTA CCGACAACTT CAGGAGCTCG TTCCCGAGTT TGATGACTAT 900 $\begin{array}{llllllllllllllllllllllllll}W & G & S & F & M & A & Y & R & Q & L & Q & E & L & V & P & E & F & D & D & Y\end{array}$

CTTATGCAAG AAGCGGCCCT CATTCAGGAC TCGTCAAGGA GCGTCCGCGA GCGCGCCGAC 960 $\begin{array}{lllllllllllllllllllll}\text { L } & M & Q & E & A & A & L & I & Q & D & S & S & R & S & V & R & E & R & A & D\end{array}$ CTTCTTGGAG CCCGTATGTT CGGTCGCTGG AAGAGCGGTA CTCCTCTTGA CCTTGCTCCA 1020 $\begin{array}{llllllllllllllllllll}\text { L } & \text { L } & G & A & R & M & F & G & R & \text { W } & \text { K } & \text { S } & \text { G } & \text { T } & \text { P } & \text { L } & \text { D } & \text { L } & \text { A } & \text { P }\end{array}$ GAGAAAGACG ACCCATCCAT CGGCCCAAAT CTTATGTTGA ACAATAACTT CGACTTCAAC 1080 $\begin{array}{llllllllllllllllllll}\mathrm{E} & \mathrm{K} & \mathrm{D} & \mathrm{D} & \mathrm{P} & \mathrm{S} & \mathrm{I} & \mathrm{G} & \mathrm{P} & \mathrm{N} & \mathrm{L} & \mathrm{M} & \mathrm{L} & \mathrm{N} & \mathrm{N} & \mathrm{N} & \mathrm{F} & \mathrm{D} & \mathrm{F} & \mathrm{N}\end{array}$ CACCCAGCGC CATTCAACAT CAATACCAAC CAATCCTACT GTCCATTCTC GGCCCACATC 1140

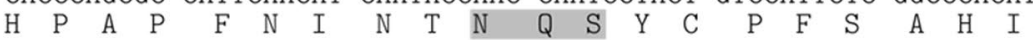

CGCAAGATTC GCCCTCGTGC TGATCAAGGA AATCAGAATC TCAAGAACCA AATGATCAGG 1200 $\begin{array}{llllllllllllllllllll}R & K & I & R & P & R & A & D & Q & G & N & Q & N & L & K & N & Q & M & I & R\end{array}$ GCCAGTATAC CTTATGGCGA AGAACTCAGC GACGACGAGA TAAACAACAA GAAGACAGGG 1260 $\begin{array}{llllllllllllllllllll}A & S & I & P & Y & G & E & E & L & S & D & D & E & I & N & N & K & K & T & G\end{array}$ ACTGAACGTG GTGTCGCATT TGTGACCTAT CAAAGTGATC TCGGTTCAGG ATTTCACTTC 1320

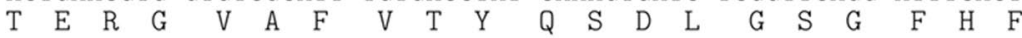
CAGCAGGCTG AATGGGCCAA CAACGTCAAC ATCCCCACTG GAAAAGCGA TCCAACACCT 1380

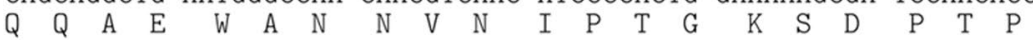
GGATTTGACC CGATTGTCGg CCAGAACAgC GgtaAACCGC TTGTTGTCTC TGGGATTGAT 1440 $\begin{array}{lllllllllllllllllllll}G & F & D & P & I & V & G & Q & N & S & G & K & P & L & V & V & S & G & I & D\end{array}$ TACACAGATC TTAACCACGA CTTGACCTTC ATGAGTTTCG TTGTTTCAAA GGGAGGGGAC 1500 $\begin{array}{llllllllllllllllllllll}Y & \mathrm{~T} & \mathrm{D} & \mathrm{L} & \mathrm{N} & \mathrm{H} & \mathrm{D} & \mathrm{L} & \mathrm{T} & \mathrm{F} & \mathrm{M} & \mathrm{S} & \mathrm{F} & \mathrm{V} & \mathrm{V} & \mathrm{S} & \mathrm{K} & \mathrm{G} & \mathrm{G} & \mathrm{D}\end{array}$ TACTTCTTCA GCCCCTCCAT GTCCGCCATC TTGCACAAAA TCGCTGCTTA A 1551 $\begin{array}{lllllllllllllllll}\mathrm{Y} & \mathrm{F} & \mathrm{F} & \mathrm{S} & \mathrm{P} & \mathrm{S} & \mathrm{M} & \mathrm{S} & \mathrm{A} & \mathrm{I} & \mathrm{L} & \mathrm{H} & \mathrm{K} & \mathrm{I} & \mathrm{A} & \mathrm{A} & *\end{array}$

Fig. 1 Nucleotide- and derived amino acid sequence of a DyP-type peroxidase from Pleurotus sapidus (LN830264). Predicted N-glycosylation sites are highlighted; a hypothetical cleavage site after 62 amino acids is marked with an arrow 
PsaDYP MRWWTTCVALTSLIPYALLPSYGFNLPQQLEARQN-----DYPSGSLLH---------DY 46 PoSDYP MRWWTCVALTSLIPYTLLPSYGFSLPQQLEARQN-----DYPSGSLLHDCVLTRLPVDY 55 BadDYP MRLS----LFVVSVAVLVGSS-SHVN--AAKLGAR-----QTRTTPLIT---------NF 39 AauDYP MRLS---PVFVALLSGLLAADLGLARSVAPRVADSPAAVTGTRKTSLLK---------NV 48 MsP1 MKLFS-ASVFAAIIASHYASATAHIR--APNVKPR-------RTNSLLT---------AP 41

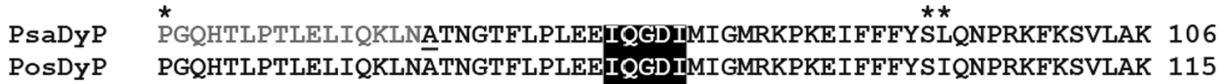
BadDYP PGQAPLPTLTQHTTESGANDTILPLNNIQGDILVGMKKQKERFVFFQVNDATSFKTALKT 99 AauDYP AGLPPVPSAAQVAATS------LNTDDIQGDILVGMHKQKQLFYFFAINDPATFKTHLAS 102 MsP1 PQQPPLPSAQQAASASSS--AGLNLTDIQGDILIGMKKNKELFFFFSITDAATFKAKLGS 99

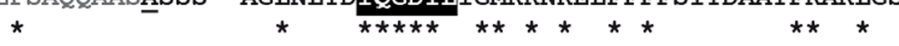

PsaDYP LIYPHITTTAQMVCTTCAQPSAMLNVAWTSQGLRKLGVLDNLGDPYFAMGQLSDAAALGD 166 PosDYP LIYPHITTTAQMVCTTCTQPSAMLNVAWTSQGLRKLGVLDDLGDPYFAMGQLNDAAALGD 175 BadDYP YVPERITSAAILISDPSQQPLAFVNLGFSNTGLQALGITDDLGDAQFPDGQFADAAN--L 157 AauDYP DIAPVVASVTQLSN-VATQPLVALNIAFSNTGLLALGVTDNLGDSLFANGQAKDATS--F 159 MSP1 DILELITSTNQLLA-VATQPITAVNVAFSSTGLKALGITDDLKDPVFEAGMLSNAVSDLS 158

PsaDYP TDPSTTWAPGLYANKTDGAFLIAAKDWEPIDTLLNQMKAWLGDAIVETHSNRGAVRPGDA 226 PosDYP TDPSTTWAPGLYANKTDGAFLIAARDWEPIDTLLNQMKNWLGDAIVETHSNRGAVRPGDA 235 BadDYP GDDLSQWVAPFTGTTIHGVFLIGSDQDDFLDQFTDDISSTFGSSITQVQALSGSARPGDQ 217 AauDYP KESTSSWVPQFAGTGIHGVIILASDTTDLIDQQVASIESTFGSSISKLYSLSASIRPGNE 219 MsP1 DPGTGNWVPGFVGTSVHGVFLLASDTIDNVNTELANIQTILNGSITEIHRLQGEARPGDQ 218

PsaDYP AGKEHFGWLDGFIQPAVAGFATS--TYPGQQLLLPGTLLTKEIGDPRRAARPAWTKWGSF 284 PosDYP AGKEHFGWLDGEIQPAVAGFATS--TYPGQQLLLPGTLLTKEIGDPRRAARPAWTKWGSF 293 BadDYP AGHEHFGFLDGISQPSVTGWETT--VFPGQAVVPPGIILTGRDGDTGT--RPSWALDGSF 273 AauDYP AGHEMFGFLDGIAQPAINGFNTP---LPGQNIVDAGVIITGATNDPIT--RPSWAVGGSF 274 MsP1 QGHEHFGFMDGISNPAVDGFTPPAEIRPGQALIPPGIMLLGEANDTFQNDRPPWAKDGSF 278

PSADYP MAYRQLQELVPEFDDYLMQEAALIQ-DSSRSVRERADLLGARMFGRWKSGTPLDLAPEKD 343 PoSDYP MAYRQLQELVPEFDDYLMQEAALIQ-DSSRSVRERADLLGARMFGRWKSGTPLDLAPERD 352 BadDYP MAFRHFQQKVPEFNAYTLANAIPANSAGNLTQQEGAEFLGARMFGRWKSGAPIDLAPTAD 333 AauDYP LAFRQLEQLVPEFNKYLLDNAP----AGSGSLQARADLLGARMVGRWKSGAPIDLTPTAD 330 MSP1 LVFRQMQQRAPEFNKFLQDHALN---MPNMTSEQGADLLGARIVGRWKSDAPIDLTPLVD 335 PsaDYP DPSIGPNLMLNNNFDFNHPAPFNINTNQSYCPFSAHIRKIRPRADQGNQNLKNQ----- 397 PosDYP DPSIGPNLMLNNNFDFNHPAPFDINSNQSYCPFSAHIRKIRPRADQGNTNLKNQ------ 406 BadDYP DPALGADPQRNNNFDYSDT-----LTDETRCPFGAHVRKTNPRQDLGGPVDTFH------ 382 AauDYP DPALGADAQRNNNFTYSHAG-FDLGSDQSHCPFSAHIRKTRPRADLGGSLTPPNLSAGAN 389 MSP1 DPVLAADNQRNNNFDFSDA------TNQTRCPFSAHIRKANPRGDLGGINKFPN-----Q 384

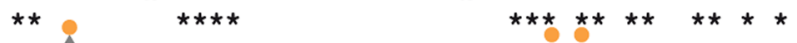

PsaDYP -MIRASIPYGEELSDDEINNKKTGT----ERGVA VTYQSDLGSGFHFQQAEWANNVNIP 452 POSDYP -MIRASIPYGEELSDDEINSKKTAT----ERGVA VTYQSDLGSGFHFQQAEWANNVNIP 461 BadDYP -AMRSSIPYGPETSDAELASGVTAQ----DRGLLVEYQSIIGNGFRFQQINWANNANFP 437 AauDYP SIMRSGIPYGPEVTSAESASNTTTQ----ERGLA VAYQAQLSQGFHFLQQTWADNANFP 445 MsP1 HIIRAGIPYGPEVTDAEKASNSSSTDPSLERGLAFVAYQSNIQNGFVFLQKNWVDNTNFF 444

PsaDYP -TGKSDPTPGFDPIVGQNS--------GKPLVVSGIDYTDLNHDLTF-MSFVVSKGGDYF 502 POSDYP -TGKSDPTPGFDPIVGQNN-------GKPLVVSGIDYTDLNHDLTF-MSFVVSKGGDYF 511 BadDYP FSKP--ITPGIEPIIGQTT---------PRTVGGLDPLNQNETFTV-PLFVIPKGGEYF 484 AauDYP -PGKTPATVGLDPIIGQNN--------GQPRVVNGLLPSNSSASLSI-PQFVVSHGGEYF 495 MsP1 RPG-----TGVDPLIGTNSRNSGTDAPNTPRVVSGLDPNNATSTIEIGIDFVVSRGGEYF 499

PsaDYP FSPSMSAILHKIAA 516

PosDYP FSPSMSAILHKIAA 525

BadDYP FLPSISALTATIAA 498

AauDYP FSPPISAIGGRLSA 509

MsP1 FSPSLSAIRTVLSV 513

$\star \star \star * \star$

Fig. 2 Alignment of various DyP-type peroxidase sequences from P. sapidus (PsaDyP), P. ostreatus (PosDyP, NCBI: CAK55151), B. adusta (BadDyP, NCBI: BAA77283), A. auricula-judae (AauDyP, NCBI: AFJ79723) and M. scorodonius (MsP1, NCBI: BOBK71). Conserved amino acids (*); the characteristic GxxDG motif is enclosed in a frame; remnants of the $\mathrm{H}_{2} \mathrm{O}_{2}$ binding site (circle); E391 (blue); conserved residues of the heme binding site (gray background); potential heme binding residues (triangle); exposed amino acids of a potential LRET (long range electron transfer, green background); remnants involved in a potential LRET (green); N-terminal conserved amino acid sequences (white); conserved histidine residues (H164 and H166, blue background); signal sequences (gray); $\mathrm{N}$-terminal amino acids are underlined 
purification step the active fractions eluted in a single, discreet peak (Fig. 3). Following the two-stage purification an electrophoretic homogeneity of DyP was achieved with a yield of $2.9 \pm 0.1 \mathrm{~g} \mathrm{~L}^{-1}$ and an increase in Reinheitszahl from 0.2 to 1.1 .

\section{Characterization of rPsaDyP}

The purified enzyme showed a typical heme-enzyme red coloring and a maximum absorbance $\lambda_{\max }=409 \mathrm{~nm}$ and two further maxima at 510 and $640 \mathrm{~nm}$ (Fig. 4). A molecular weight of $57.6 \mathrm{kDa}$ was determined by SDS-PAGE. Isoelectric focusing (IEF) showed a pl of 6.7 (Fig. 4).

\section{Determination of the native conformation}

The native conformation of the $\mathrm{DyP}$ was established by Blue Native PAGE and gel filtration chromatography. By electrophoresis a molecular weight of $115 \mathrm{kDa}$ was ascertained for the native, active enzyme and the retention time of the peaks in gel filtration chromatography indicated an apparent molecular weight of $122 \mathrm{kDa}$. The molecular weights indicated by these two methods were comparable and approximately double the value of the apparent molecular weight of $\mathrm{rPsaDyP}$ under denaturing conditions $(57.6 \mathrm{kDa})$. This suggests that the quaternary structure of the native enzyme is a dimer.

Four potential $\mathrm{N}$-glycosylation sites were predicted in the amino acid sequence. The protein was therefore treated with PNGase F in order to remove any possible oligosaccharides from the $\mathrm{N}$-glycosylation sites. After treatment with the glycosidase rPsaDyP showed a lower apparent molecular weight in SDS-PAGE than the untreated samples $(52.8-57.6 \mathrm{kDa})$. This indicates that rPsaDyP is glycosylated by the host organism. From the difference in molecular weights a degree of glycosylation of $\sim 9 \%$ was calculated.

\section{$\mathrm{N}$-terminus}

The detected apparent molecular weight of the deglycosylated $\mathrm{rPsaDyP}$ is lower than the theoretical weight that was calculated from the primary sequence. This suggests that the protein is processed in the host organism. Therefore, the $\mathrm{N}$-terminus of the recombinant enzyme was determined by Edman degradation. The first 12 residues of the $\mathrm{N}$-terminal amino acid sequence of the purified enzyme (AT(N)GTFLPLEEI) were identified. According to this the enzyme has a signal peptide 62 amino acids long and the mature protein a total length of 454 amino acids.

\section{Catalytic properties of rPsaDyP $\mathrm{pH}$ - and temperature optimum}

Before the kinetic constants were determined the optimal $\mathrm{pH}$ for oxidation of the substrate investigated was identified (Fig. 5). The pH-optimum for the oxidation of ABTS and Rblue 5 was found to be between 3.5 and 4.0, for the reaction with phenolic substrates the $\mathrm{pH}$-optimum was

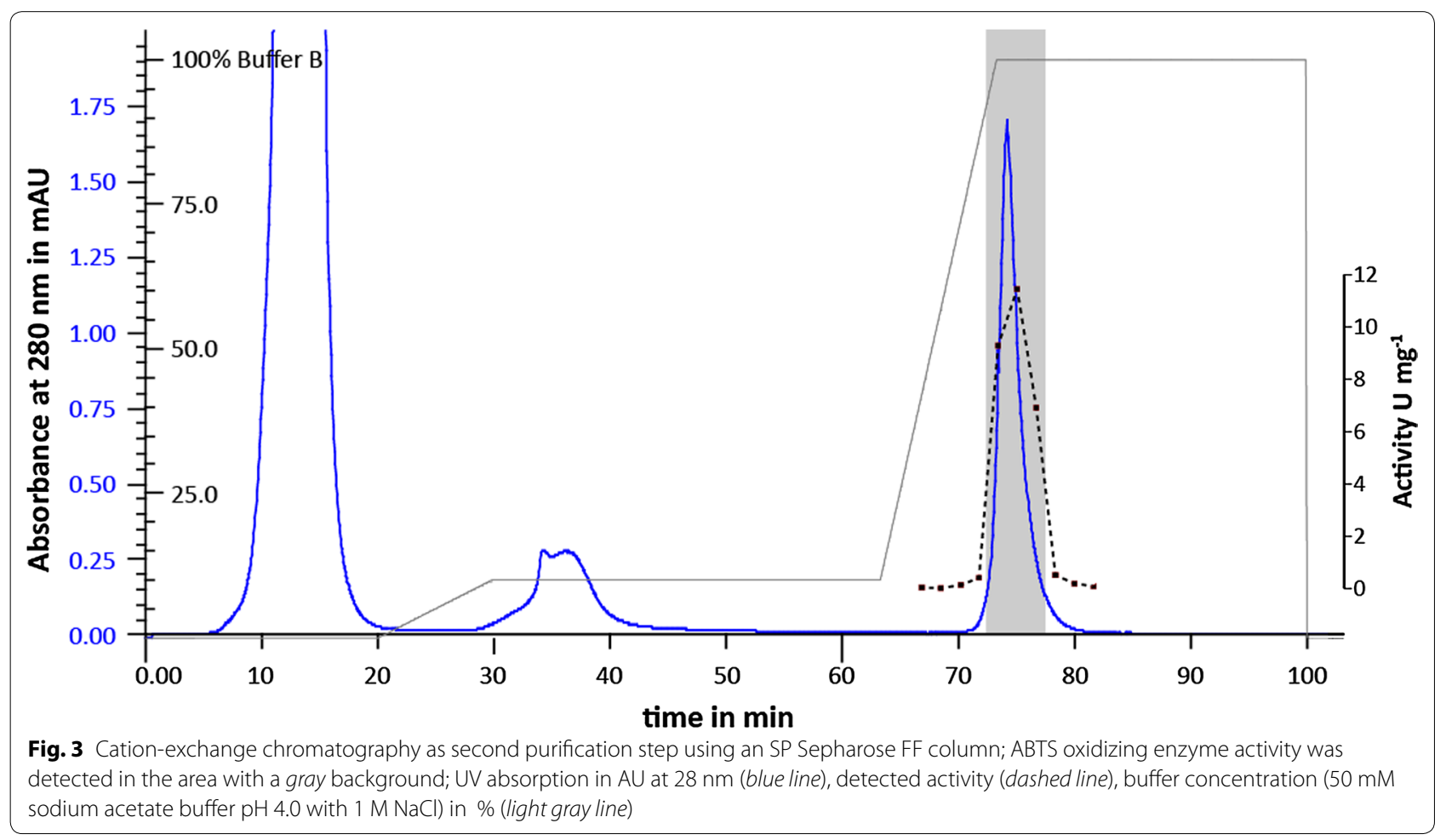



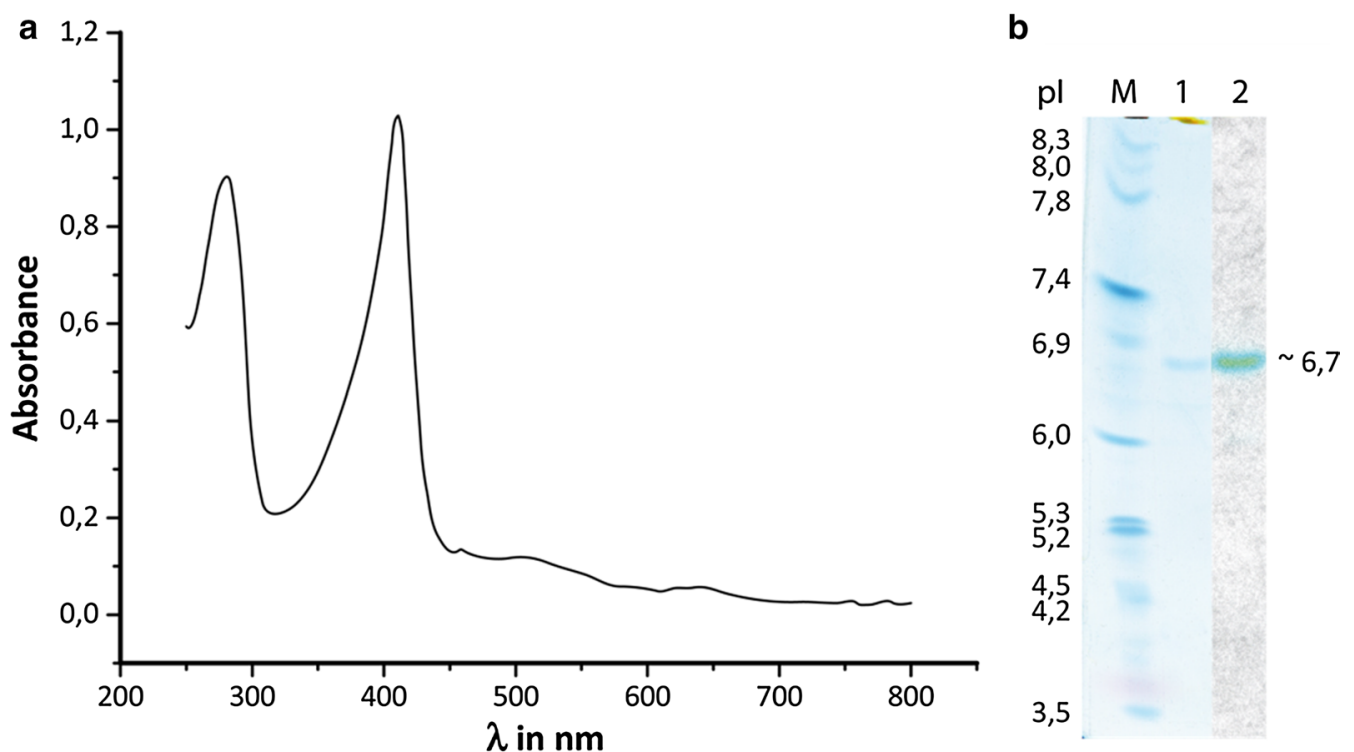

Fig. 4 a UV-Vis absorption spectrum of the purified rPsaDyP showing the Soret band at $409 \mathrm{~nm}$ and two additional maxima in the region of 510 and $640 \mathrm{~nm}$; $\mathbf{b}$ isoelectric focusing of purified rPsaDyP, stained with colloidal Coomassie (1) and specific staining for heme/metal enzymes with TMB (2); M IEF Marker 3-10
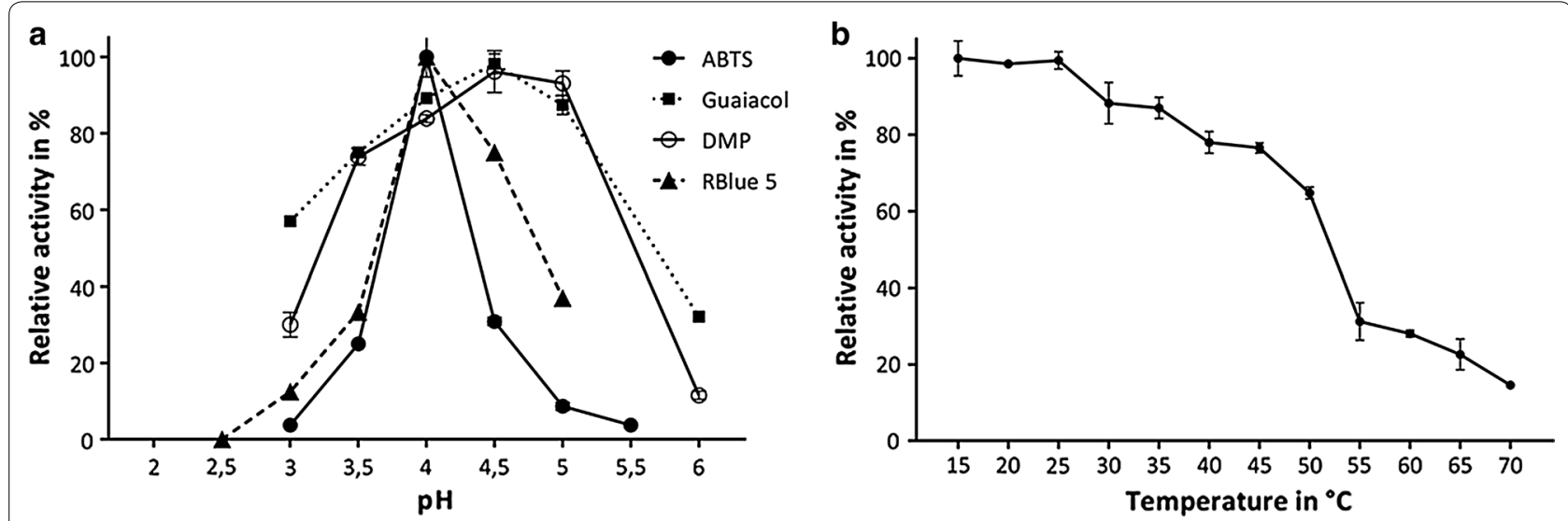

Fig. 5 a Optimum pH value for oxidation of ABTS, DMP and guaiacol by rPsaDyP in 50 mM sodium acetate buffer or Rblue 5 in $100 \mathrm{mM}$ sodium tartrate buffer. $\mathbf{b}$ Effect of temperature on the activity of rPsaDyP with ABTS as substrate

higher ( $\mathrm{pH} 4.5)$. In addition, the enzyme activity for the substrates was determined under varying $\mathrm{H}_{2} \mathrm{O}_{2}$ concentrations $(0-1250 \mu \mathrm{M})$. With ABTS as substrate the peroxidase activity fell significantly when the $\mathrm{H}_{2} \mathrm{O}_{2}$ concentration rose above $0.125 \mathrm{mM}$, indicating that the enzyme is inhibited by $\mathrm{H}_{2} \mathrm{O}_{2}$. Maximum reaction rates depending upon substrate tested reached values between 31.2 and $125 \mu \mathrm{M}(31.2 \mu \mathrm{M}$ : RBlue 5, $62.5 \mu \mathrm{M}$ : DMP, guaiacol, RBlack 5; ABTS, Annatto, Bixin, $\beta$-carotene: $125 \mu \mathrm{M}$ ).

The enzyme showed maximum activity over a temperature range of $15-30{ }^{\circ} \mathrm{C}$. To determine the thermal stability residual activity was detected after a $5 \mathrm{~min}$ incubation of the enzyme. At temperatures over $70{ }^{\circ} \mathrm{C}$ the enzyme completely lost activity. A $5-\min \mathrm{T}_{50}$-Wert of $53{ }^{\circ} \mathrm{C}$ was determined from the residual activity of the enzyme. Under assay conditions the enzyme showed a $75 \%$ residual activity after $2 \mathrm{~h}$ and after $24 \mathrm{~h} 40 \%$ of the initial activity was still present.

\section{Catalytic properties}

The apparent kinetic constant for rPsaDyP (expressed in $T$. reese $i$ as active protein) was determined for ABTS, 
RBlue 5, DMP and guaiacol as shown in Table 1. The peroxidase efficiently oxidized the low redox potential dye ABTS. In addition, rPsaDyP catalyzed the degradation of the dye Rblue5, a characteristic DyP substrate. The enzyme binds this substrate at high affinity $\left(\mathrm{K}_{\mathrm{m}}=24 \mu \mathrm{M}\right)$ and converts it efficiently. The substrate spectrum of rPsaDyP also includes the substituted phenols DMP and guaiacol. Both of these substrates show a high $\mathrm{K}_{\mathrm{m}}(713$ and $1227 \mu \mathrm{M}$, respectively) and a relatively low catalytic efficiency compared to the other substrates.

DyP is also able to catalyze the degradation of the natural pigment $\beta$-carotene ene $\left(90 \mathrm{U} \mathrm{L}^{-1}\right)$. A study of the kinetics of the conversion of this substrate was difficult, however, since only low substrate concentrations (maximal $26 \mu \mathrm{M})$ could be used in the assay and thus saturation of the enzyme could not be achieved. Notably, the DyP-type peroxidase can convert this substrate without the addition of $\mathrm{H}_{2} \mathrm{O}_{2}$ in the same manner as MsP1 and MsP2 (Scheibner et al. 2008; Zorn et al. 2003b). At the same time, enrichment of the buffer with $\mathrm{O}_{2}$ increased the conversion rate by a factor of 2.3 compared to standard conditions without addition of $\mathrm{H}_{2} \mathrm{O}_{2}$. The enzymatic conversion was virtually halted when degassed buffer was used (Table 2). This indicates that the enzyme also possesses oxidase or oxygenase activity.

Furthermore, the enzyme can also convert additional natural pigments such as bixin and annatto (90 and 114. $\left.\mathrm{U} \mathrm{L}^{-1}\right)$, as well as high redox potential dyes such as RBlack $5\left(231 \mathrm{U} \mathrm{L}^{-1}\right)$.

\section{Discussion}

The first published sequence of a DyP-type peroxidase originated from the Basidiomycetes B. adusta (Kim and Shoda 1999b). In the meantime further DyP-type peroxidases from white-rot fungi have been cloned and sequenced, including $P$. ostreatus, $M$. scorodonius und $A$. auricula-judae (Faraco et al. 2007; Scheibner et al. 2008; Liers et al. 2010). X-ray structural analysis has only been performed on two DyP-type peroxidases from fungi. The first DyP-peroxidase structure examined was from B. adusta (BadDyP; PDB-Code 2D3Q). In the meantime the structure of a DyP from A. auricula-judae (AauDyP; PDB-Code 4AU9) has also been elucidated. In the present study the first DyP-type peroxidase from P. sapidus
Table 2 Degradation of $\beta$-carotene by the purified recombinant DyP-type peroxidase from Pleurotus sapidus (in the absence of $\mathrm{H}_{2} \mathrm{O}_{2}$ ) under standard assay conditions, in oxygen saturated buffer, and under anoxic conditions

\begin{tabular}{llll}
\hline $\begin{array}{l}\text { Enzyme concen- } \\
\text { tration }(\mathrm{nM})\end{array}$ & $\boldsymbol{v}\left(\boldsymbol{\mu M \mathbf { m i n } ^ { - 1 } )}\right.$ & & \\
\cline { 2 - 4 } & Degassed buffer & $\begin{array}{l}\text { Standard assay } \\
\text { conditions }\end{array}$ & $\begin{array}{l}\text { Oxygen } \\
\text { saturated } \\
\text { buffer }\end{array}$ \\
\hline 270 & 0.045 & 0.385 & 0.878 \\
360 & 0.056 & 0.495 & 1.069 \\
540 & 0.077 & 0.532 & 1.217 \\
\hline
\end{tabular}

was cloned and sequenced. By comparing the converted amino acid sequence with other DyP-type peroxidases, and with the structural homology model of the structure of AauDyP as a basis, shared motifs and catalytic residues could be identified. The model demonstrates the characteristic $\beta$-barrel structure and environment of the heme pocket. This includes the characteristic GxxDG motif with the conserved aspartate that, together with the conserved arginine residue is situated on the distal side of the heme, as well as the proximal histidine. The alignment shows that the amino acids involved in the heme binding as well as those involved in catalysis are highly conserved.

DyP-type peroxidases are also capable of oxidizing large substrates that are not able to reach the immediate proximity of the heme in the active center. For this reason it is a matter of discussion as to whether these enzymes exclusively possess solvent-exposed substrate binding sites (Liers et al. 2013a). Strittmatter et al. (2013) identified potential LRET transfer pathways in the DyP-type peroxidase from $A$. auricula-judae. A number of exposed residues on the protein surface (Trp or Tyr) serve as oxidation site for large substrates. Linde et al. (2015a, b) recently showed that LRET from AauDyP essentially begins at W377 that is also conserved in rPsaDyP.

The histidine 164 or 166 (BadDyP) are conserved in many DyP sequences. It was therefore long a matter of discussion whether these residues function as proximal histidine or as heme ligand. Sugano et al. (2004) showed that H166 is not essential for the peroxidase activity. On the other hand, the authors showed that mutant

Table 1 Apparent kinetic constants of the recombinant DyP-type peroxidase from Pleurotus sapidus

\begin{tabular}{lllcccc}
\hline Substrate & $\mathbf{p H}$ & Enzyme concentration $(\mathbf{n M})$ & $\boldsymbol{K}_{\mathbf{m}}(\boldsymbol{\mu M})$ & $\boldsymbol{k}_{\text {cat }}\left(\mathbf{s}^{\mathbf{- 1}}\right)$ & $\boldsymbol{k}_{\text {cat }} \boldsymbol{K}_{\mathbf{m}}^{-\mathbf{1}}\left(\mathbf{s}^{\mathbf{- 1}} \mathbf{M}^{-\mathbf{1}}\right)$ & $\boldsymbol{v}_{\text {max }}\left(\boldsymbol{\mu} \mathbf{M ~ s} \mathbf{~}^{\mathbf{- 1}}\right)$ \\
\hline ABTS & 3.8 & 0.27 & 99 & 375 & $3.8 \times 10^{6}$ & 0.10 \\
DMP & 4.5 & 1.8 & 1227 & 60 & $4.9 \times 10^{4}$ & 0.11 \\
Guaiacol & 4.5 & 4.5 & 713 & 74 & $1.0 \times 10^{5}$ & 0.35 \\
RBlue 5 & 4.0 & 5.4 & 24 & 18 & $7.5 \times 10^{5}$ & 0.10 \\
\hline
\end{tabular}


H164A completely lost the activity. This result indicates that H164 is not directly involved in heme binding, but rather suggests only a decrease in protein stability and a loss of the heme-binding affinity (Faraco et al. 2007). $\mathrm{H} 164$ is not conserved in rPsaDyP or in PosDyP, but is replaced by a lysine (K167). This exchange is also found in various other representatives of the DyP-type peroxidase family, for instance in the proteins of $A$. oryzae (Q2UPE9, Q2U1I3), Neurospora crassa (Q7S3A4) and various other members of the DyP-family (Faraco et al. 2007). This suggests that $\mathrm{H} 164$ is not directly involved in heme binding and another residue coordinates the heme in DyP-type peroxidases. Nonetheless, according to Sugano (2009) H164 plays an important role in the folding of DyP-type peroxidases and binding of heme, even if it is not conserved in all members of this protein family. Here the situation is different than described by the authors. Histidine does not appear to be crucial for folding, but rather, a basic amino acid in this position. Johjima et al. (2003) identified 10 potential ligands (His, Tyr und Cys) for heme. For AauDyp Strittmatter et al. (2013) showed that on the proximal side arginine 255 and 311 form hydrogen bonds to the propionate residues of heme and are involved in the coordination of heme. The homologous residues from $\mathrm{rPsaDyP}$ were identified (at position 267 and 324) and in the model are at a distance of 3.2 and $3.5 \AA$, respectively, to the propionates.

\section{Heterologous expression}

The DyP-type peroxidase from Pleurotus sapidus was successfully expressed heterologously in the ascomycete $T$. reesei and the active enzyme was secreted into the culture supernatant. An activity of $55,000 \mathrm{U} \mathrm{L}^{-1}$ was determined for the recombinant DyP-type peroxidase in the supernatant with the substrate ABTS. Heterologous expression of the DyP from B. adusta in $A$. oryzae imparted a 42 fold increase in activity with the substrate RBlue $5\left(8 \times 10^{2} \mathrm{U} \mathrm{L}^{-1}\right)$ over that in the culture medium (Sugano et al. 2000). Heterologous expression of the PsaDyP from T. reesei led to an order of magnitude higher activity $\left(5 \times 10^{3} \mathrm{U} \mathrm{L}^{-1}\right)$ with RBlue 5. PsaDyP could be efficiently expressed in $T$. reesei and unusually high activities could be achieved. The recombinant enzyme showed the characteristic absorption maximum at $409 \mathrm{~nm}$ (Soret-Band) and two further maxima ( $\alpha$ and $\beta$ ) in the region of $640 \mathrm{~nm}$ that are attributed to the porphyrin structure of heme (Glenn and Gold 1985; Renganathan and Gold 1986).

\section{Native conformation}

A glycosylation degree of $9 \%$ was determined for the DyP-type peroxidase heterologously expressed in $T$. reesei, a carbohydrate content that is comparable with that of the DyP-type peroxidase MsP2 (Scheibner et al. 2008). The carbohydrate content of DyP-type peroxidases lies typically between 9 and 31\% (Hofrichter et al. 2010).

After deglycosylation the apparent molecular weight determined in SDS-PAGE was lower for rPsaDyP heterologously expressed in $T$. reesei than was calculated from the primary sequence. This implies that the enzyme, just as with BadDyP in A. oryzae (Sugano et al. 2000), is further processed in the host organism, T. reesei. The $\mathrm{N}$-terminus of the recombinant enzyme was sequenced by Edman degradation. Processing of rPsaDyP is between amino acids 62 and 63. Sugano et al. (2000) showed that the recombinant DyP-type peroxidase from $B$. adusta produced in $A$. oryzae has the same $\mathrm{N}$-terminus as the wild-type enzyme. This suggests that the recombinant and native PsaDyP have the same $\mathrm{N}$-terminus. Studies of other DyP-type peroxidases show that processing occurs between position 56/57 (BadDyP), 55/56 (MsP1), 57/58 (MsP2) and 61/62 (AauDyP) (Liers et al. 2010; Scheibner et al. 2008; Sugano et al. 2000). In rPsaDyP a cluster of conserved amino acids is present in the region of the $\mathrm{N}$-terminus, however a typical cleavage site was not found (Liers et al. 2010).

In contrast to the classical DyP rPsaDyP occurs as a dimer, whereby it must be noted that various other DyP-type peroxidases, especially from prokaryotes, form numerous higher quaternary structures ranging from monomers to hexamers. The reason for this oligomerization has been subject of discussion, but remains unknown. Sugano (2009) showed that the classical DyP, compared to DyP-type peroxidases that form oligomers, exhibit insertions in the primary sequence that are missing in the former. Nonetheless, the primary sequences of MsP1 and MsP2 exhibit a high degree of homology to BadDyP and like rPsaDyP and have these insertions, and yet they occur natively as dimers (Scheibner et al. 2008).

\section{Biochemical characterization}

DyP-type peroxidases are typically secreted glycoproteins with molecular weights of 40-67 kDa (in monomeric form) and isoelectric points in the acid range (3.5-4.3, Hofrichter et al. 2010). A monomer of rPsaDyP has a molecular weight of $57.4 \mathrm{kDa}$ and therefore is of average size for an enzyme of the family of DyP-type peroxidases. In contrast to other enzymes of this family rPsaDyP has an apparent $\mathrm{Pl}$ within the neutral range. Lignolytic peroxidases from fungi (LiP, VP, DyP), like plant peroxidases demonstrate maximum activity in an acidic milieu (pH 1.5-5.0, Camarero et al. 1999; Gazarian et al. 1996; Liers et al. 2010; McEldoon et al. 1995). Depending upon the substrate, the $\mathrm{pH}$ profile of $\mathrm{rPsaDyP}$ shows an activity maximum between $\mathrm{pH} 3.5$ and 4.5 (with the exception of Annatto at $\mathrm{pH}$ 6.0). Thus, the profile is shifted to 
somewhat higher $\mathrm{pH}$ values compared to other DyP-type peroxidases. Maximum activity of $\mathrm{rPsaDyP}$ was shown between 15 and $30{ }^{\circ} \mathrm{C}$. This is comparable with that of BadDyP (Kim and Shoda 1999a). Above $35^{\circ} \mathrm{C}$ activity of rPsaDyP decreased continuously and $\sim 65 \%$ remained at $50{ }^{\circ} \mathrm{C}$. $\mathrm{rPsaDyP}$ is active in a wide range of temperatures and $\mathrm{pH}$ values. It remains active for a number of hours in sodium acetate buffer between $\mathrm{pH} 3$ and $\mathrm{pH} 6$ and maintains up to $60 \%$ of its initial activity after $24 \mathrm{~h}$ (data not shown). There is a tendency for the activity of the enzyme to remain stable at higher $\mathrm{pH}$ values. After $24 \mathrm{~h}$ under reaction conditions it retains more than $40 \%$ of its initial activity (data not shown).

\section{Influence of hydrogen peroxide on enzyme activity}

With ABTS as substrate the peroxidase activity dropped significantly if the $\mathrm{H}_{2} \mathrm{O}_{2}$ concentration rose above $0.125 \mathrm{mM}$. Inhibition of peroxidase activity by an excess of hydrogen peroxide via suicide inactivation has long been known (Arnao et al. 1990), but has not been fully resolved for DyP-type peroxidases. Maximal activity was achieved at an $\mathrm{H}_{2} \mathrm{O}_{2}$ concentration of $0.125 \mathrm{mM}$. For the substrates Rblue 5, DMP, guaiacol and RBlack 5 activity was inhibited at lower $\mathrm{H}_{2} \mathrm{O}_{2}$ concentrations. The inhibition of the enzyme activity strongly depends upon enzyme and substrate concentration. Kim and Shoda (1999a) demonstrated that the degree of inhibition varied greatly depending on the substrate used. In previously described inhibition pathways Compound II plays an important role, however, the existence of Compound II has not been confirmed in DyP-type peroxidases (Hofrichter et al. 2010; Sugano et al. 2007). The catalytic cycle described for classical peroxidases in the presence of reducing substrates begins with the oxidation to Compound I by the transfer of two electrons to $\mathrm{H}_{2} \mathrm{O}_{2}$. By the transfer of a single electron from the reduced substrate Compound II is formed, which in turn is reduced to the native enzyme through reaction with an additional substrate molecule. In the presence of excess $\mathrm{H}_{2} \mathrm{O}_{2}$ Compound II reacts with $\mathrm{H}_{2} \mathrm{O}_{2}$ to form Compound III (inactive form). This does not necessarily imply a final exclusion of the enzyme from the catalytic cycle. In the case of horseradish peroxidase there are indications that the enzyme slowly returns to the initial state through spontaneous decay of Compound III, giving rise to a superoxide. Furthermore, Compound III can be reduced to Compound I by various electron donors, allowing it to re-enter the catalytic cycle (Dequaire et al. 2002). Koduri and Tien (1995) showed that the substrate guaiacol or the phenoxyl radical were only partially able to transform Compound III to the initial state and are considerably less efficient at this process than veratryl alcohol. Dequaire et al. (2002) presented similar results for horseradish peroxidase. Compound III was reduced to Compound I by various electron donors. A similar substrate dependent mechanism may explain the divergent inhibition of the enzyme by hydrogen peroxide in rPsaDyP.

\section{Catalytic properties}

From the functional standpoint the heterologously expressed peroxidase of $P$. sapidus can be assigned to the class of DyP-type peroxidases as based on its substrate spectrum and the efficient oxidation of RBlue 5 . The enzyme binds RBlue 5 with the highest affinity $(K \mathrm{~m}=24 \mu \mathrm{M})$ of all the substrates studied. The affinity to this substrate is comparable with the affinity of DyPtype peroxidase from $B$. adusta $(54 \mu \mathrm{M})$ and A. auricula-judae $(23 \mu \mathrm{M})$ (Kim and Shoda 1999a; Liers et al. 2010). Although the binding affinity to the dye RBlue 5 by $\mathrm{rPsaDyP}$ is comparable, the decolorization rate of $7.5 \times 10^{5} \mathrm{~s}^{-1} \mathrm{M}^{-1}$ indicates a sixfold lower catalytic efficiency than for BadDyP and AauDyp $\left(4.8 \times 10^{6} \mathrm{~s}^{-1} \mathrm{M}^{-1}\right.$ and $5 \times 10^{6} \mathrm{~s}^{-1} \mathrm{M}^{-1}$, respectively).

The affinities of rPsaDyP for ABTS and unsubstituted phenols are lower. Nonetheless, the highest activity and catalytic efficiency was found for ABTS. The catalytic efficiency of rPsaDyP is $3.8 \times 10^{6} \mathrm{~s}^{-1} \mathrm{M}^{-1}$ and is therefore comparable to the catalytic efficiency of the DyP-type peroxidase from Irpex lacteus (IlaDyP) $\left(8.0 \times 10^{6} \mathrm{~s}^{-1} \mathrm{M}^{-1}\right.$; Salvachúa et al. 2013) and lower than that of AauDyP $\left(1.8 \times 10^{7} \mathrm{~s}^{-1} \mathrm{M}^{-1}\right.$; Liers et al. 2010) and MscDyP $\left(6.3 \times 10^{7} \mathrm{~s}^{-1} \mathrm{M}^{-1}\right.$; Szweda et al. 2013). The affinity of rPsaDyP is, however, also somewhat lower than the affinities of AauDyP and MscDyP to ABTS.

The substituted phenols DMP and guaiacol, which serve as classical substrates for MnP, are oxidized by rPsaDyP. The turnover number $k_{\text {cat }}$ for the oxidation of DMP $\left(k_{\text {cat }}=60 \mathrm{~s}^{-1}\right)$ or guaiacol $\left(k_{\mathrm{cat}}=74 \mathrm{~s}^{-1}\right)$ are comparable with those of other DyP-type peroxidases (AauDyP: $k_{\text {cat }}=90 \mathrm{~s}^{-1}$ and IlaDyP: $k_{\text {cat }}=70 \mathrm{~s}^{-1}$; Liers et al. 2010; Salvachúa et al. 2013) and manganese peroxidase (Bad MnP for DMP: $k_{\text {cat }}=70 \mathrm{~s}^{-1}$; Wang et al. 2002) and higher than those for lignin peroxidases (DMP: $k_{\text {cat }}=27 \mathrm{~s}^{-1}$, guaiacol: $k_{\text {cat }}=38 \mathrm{~s}^{-1}$; Ward et al. 2003) and the versatile peroxidases (for the oxidation of DMP without Mn(II): VP from Pleurotus eryngii: $k_{\mathrm{cat}}=3 \mathrm{~s}^{-1}$ or BadVP: $k_{\text {cat }}=2.3 \mathrm{~s}^{-1}$; Camarero et al. 1999; Mester and Field 1998). The $K_{m}$-values for rPsaDyP are relatively high compared to DyP-type peroxidases so that catalytic efficiency is about a fold lower.

Rblack 5 is a dye and a specific substrate for VP (Camarero et al. 1999; Heinfling et al. 1998). Liers et al. (2013b) showed that a number of DyP-type peroxidases oxidize Rblack 5. rPsaDyP oxidizes RBlack 5 at low efficiency $\left(0.1 \mathrm{U} \mathrm{mg}^{-1}\right)$. 
Degradation of $\beta$-carotene and annatto (a dye mixture of the xanthophylls bixin und norbixin) was demonstrated using the purified enzyme. An aqueousalkaline extract, the principle component of which was the sodium salt of norbixin, was used for the oxidation of annatto (Scotter et al. 1998). The degradation of bixin was also used to determine whether rPsaDyP can oxidize both xanthophylls. The enzyme also oxidizes bixin. It should be noted that higher activities were determined for norbixin (as an aqueous-alkaline annatto extract) at lower substrate concentrations (15-19 $\mu \mathrm{M})$. A comparable activity was measured for the oxidation of the hydrophobic substrates bixin and and $\beta$-carotene at the same substrate concentrations $(19 \mu \mathrm{M})$.

rPsaDyP can oxidize $\beta$-carotene without addition of $\mathrm{H}_{2} \mathrm{O}_{2}$, however enzyme activity was enhanced by adding $\mathrm{H}_{2} \mathrm{O}_{2}$. Enrichment of the reaction buffer with $\mathrm{O}_{2}$ also increased the transformation of $\beta$-carotene, and conversely, degassing the buffer slowed down the reaction. This indicates that the decomposition of $\beta$-carotene is directly dependent upon the concentration of molecular oxygen in the buffer. In addition, this implies that the in addition to the peroxidase function there is an oxidase- or oxygenase function (Sugano 2009). Zorn et al. (2003a) also showed that $\beta$-carotene is degraded in an oxygen-dependent reaction by a cell-free supernatant of a Mycetinis scorodonius culture. In other studies Scheibner (2006) and Hülsdau (2007) showed that the oxidation of $\beta$-carotene by the purified DyP-type peroxidase MsP1 from culture supernatant can take place without addition of $\mathrm{H}_{2} \mathrm{O}_{2}$, whereby the enzyme activity was increased by addition of $\mathrm{H}_{2} \mathrm{O}_{2}$. An $\mathrm{H}_{2} \mathrm{O}_{2}$ independent reaction was described for the oxidation of epinephrine by horseradish peroxidase or for the oxidation of Indol-3-acetic acid by plant peroxidases (Adak et al. 1998; Gazarian et al. 1998). Here, an autocatalytic process was suggested in which superoxide radicals are formed in the presence of molecular oxygen. These can in turn form peroxides that can be utilized by the peroxidases (Adak et al. 1998; Gazarian et al. 1998).

Due to their versatility DyP-type peroxidases may, in addition to the degradation of lignocelluloses and other polymers, take part in an unspecific pathogen defense and in detoxification processes (Liers et al. 2013b; Zámocký et al. 2009).

\footnotetext{
Abbreviations

AA: amino acid; ABTS: 2,2'-azino-bis(3-ethylthiazoline-6-sulfonate); DMP: dimethoxyphenol; DyP-tyxpe peroxidase: dye decolorizing peroxidase; FPLC: fast protein liquid chromatography; GFC: gel filtration chromatography; IEF: isoelectric focusing; LiP: lignin peroxidases; LRET: long range electron transfer: MnP: manganese peroxidases; MscDyP: recombinant dye decolorizing peroxidase cloned from Mycetinis scorodonius; PAGE: polyacrylamide gel electrophoresis; pl: isoelectric point; Rblack 5: Reactive Black 5 dye; Rblue 5: Reactive Blue 5 dye; rPsaDyP: recombinant dye decolorizing peroxidase cloned from Pleurotus sapidus; TMB: 3,3',5,5'-tetramethylbenzidine; VP: versatile peroxidases.
}

\section{Authors' contributions}

$\mathrm{CL}$ performed the experimental work on enzyme purification and its biochemical characterization and wrote the manuscript, TS, QKN, and PL: were responsible for the cloning and heterologous expression of the peroxidase, $G L$ performed the Edman degradation, and $\mathrm{HZ}$ designed the study. All authors read and approved the final manuscript.

\section{Author details \\ ${ }^{1}$ Institute of Food Chemistry and Food Biotechnology, Justus Liebig University Giessen, Heinrich-Buff-Ring 17, 35392 Giessen, Germany. ${ }^{2}$ AB Enzymes GmbH, Feldbergstrasse 78, 64293 Darmstadt, Germany. ${ }^{3}$ Institute of Biochemistry, Justus Liebig University Giessen, Friedrichstrasse 24, 35392 Giessen, Germany. ${ }^{4}$ Bioresources Project Group, Fraunhofer Institute for Molecular Biology and Applied Ecology (IME), Winchesterstrasse 2, 35394 Giessen, Germany.}

\section{Acknowledgements}

Assistance by Bruce Boschek in drafting of the manuscript is gratefully acknowledged.

\section{Competing interests}

The authors declare that they have no competing interests.

\section{Availability of data and materials}

We conducted experiments and data were generated. All data is shown in Figures and Tables within the article.

\section{Consent for publication}

Not applicable.

\section{Ethics approval and consent to participate}

Not applicable.

\section{Funding}

We wish to express our gratitude to the Deutschen Bundesstiftung Umwelt (DBU) for financial support of the research Project (AZ 13211-32). HZ was financially supported by the excellence initiative of the Hessian Ministry of Science and Art which encompasses a generous grant for the LOEWE centre "Insect Biotechnology and Bioresources".

\section{Publisher's Note}

Springer Nature remains neutral with regard to jurisdictional claims in published maps and institutional affiliations.

Received: 27 May 2017 Accepted: 17 August 2017

Published online: 23 August 2017

\section{References}

Adak S, Bandyopadhyay U, Bandyopadhyay D, Banerjee RK (1998) Mechanism of horseradish peroxidase catalyzed epinephrine oxidation: obligatory role of endogenous $\mathrm{O}_{2}{ }^{-}$and $\mathrm{H}_{2} \mathrm{O}_{2}$. Biochemistry 37:16922-16933

Ahmad M, Roberts JN, Hardiman EM, Singh R, Eltis LD, Bugg TDH (2011) Identification of DypB from Rhodococcus jostii RHA1 as a lignin peroxidase. Biochemistry 50:5096-5107

Arnao MB, Acosta M, del Ría-Cánovas F (1990) A kinetic study on the suicide inactivation of peroxidase by hydrogen peroxide. Biochim Biophys Acta 1041:43-47

Ben Aziz A, Grossman S, Ascarelli I, Budowski P (1971) Carotene-bleaching activities of lip-oxygenase and heme proteins as studied by a direct spectrophotometric method. Phytochemistry 10:1445-1452

Bradford MM (1976) A rapid and sensitive method for the quantitation of microgram quantities of protein utilizing the principle of protein-dye binding. Anal Biochem 72(1-2):248-254

Camarero S, Sarkar S, Ruiz-Dueñas FJ, Martínez ÁT (1999) Description of a versatile peroxidase involved in the natural degradation of lignin that has both manganese peroxidase and lignin peroxidase substrate interaction sites. J Biol Chem 274:10324-10330 
Dequaire M, Limoges B, Moiroux J, Savéant J (2002) Mediated electrochemistry of horseradish peroxidase. Catalysis and inhibition. J Am Chem Soc 124:240-253

Eggert C, Temp U, Eriksson KE (1996) The ligninolytic system of the white rot fungus Pycnoporus cinnabarinus: purification and characterization of the laccase. Appl Environ Microbiol 62:1151-1158

Faraco V, Piscitelli A, Sannia G, Giardina P (2007) Identification of a new member of the dye-decolorizing peroxidase family from Pleurotus ostreatus. World J Microbiol Biotechnol 23:889-893

Fernández-Fueyo E, Linde D, Almendral D, López-Lucendo MFJ, Martínez ÁT (2015) Description of the first fungal dye-decolorizing peroxidase oxidizing manganese(II). Appl Microbiol Biotechnol 99:8927-8942

Gazarian IG, Lagrimini LM, George SJ, Thorneley RN (1996) Anionic tobacco peroxidase is active at extremely low $\mathrm{pH}$ : veratryl alcohol oxidation with a pH optimum of 1.8. Biochem J 320:369-372

Gazarian IG, Lagrimini LM, Mellon FA, Naldrett MJ, Ashby GA, Thorneley RN (1998) Identification of skatolyl hydroperoxide and its role in the peroxidase-catalysed oxidation of indol-3-yl acetic acid. Biochem J 333(Pt 1):223-232

Glenn JK, Gold MH (1985) Purification and characterization of an extracellular Mn(II)-dependent peroxidase from the lignin-degrading basidiomycete Phanerochaete chrysosporium. Arch Biochem Biophys 242:329-341

Heinfling A, Martínez ÁT, Bergbauer M, Szewzyk U (1998) Transformation of industrial dyes by manganese peroxidases from Bjerkandera adusta and Pleurotus eryngii in a manganese-independent reaction. Appl Environ Microbiol 64:2788-2793

Henne KR, Kunze KL, Zheng YM, Christmas P, Soberman RJ, Rettie AE (2001) Covalent linkage of prosthetic heme to CYP4 family P450 enzymes. Biochemistry 40:12925-12931

Hofrichter M, Ullrich R, Pecyna MJ, Liers C, Lundell T (2010) New and classic families of secreted fungal heme peroxidases. Appl Microbiol Biotechnol 87:871-897

Hülsdau B (2007) Oxidativer Abbau von Carotinoiden durch Pilzenzyme. Gottfried Wilhelm Leibniz Universität, Hannover

Husain Q (2006) Potential applications of the oxidoreductive enzymes in the decolorization and detoxification of textile and other synthetic dyes from polluted water: a review. Crit Rev Biotechnol 26:201-221

Johjima T, Ohkuma M, Kudo T (2003) Isolation and cDNA cloning of novel hydrogen peroxide-dependent phenol oxidase from the basidiomycete Termitomyces albuminosus. Appl Microbiol Biotechnol 61:220-225

Kang D, Gho YS, Suh M, Kang C (2002) Highly sensitive and fast protein detection with Coomassie brilliant blue in sodium dodecyl sulfate-polyacrylamide gel electrophoresis. Bull Korean Chem Soc 23:1511-1512

Kim SJ, Shoda M (1999a) Decolorization of molasses and a dye by a newly isolated strain of the fungus Geotrichum candidum Dec 1. Biotechnol Bioeng 62:114-119

Kim SJ, Shoda M (1999b) Purification and characterization of a novel peroxidase from Geotrichum candidum Dec 1 involved in decolorization of dyes. Appl Environ Microbiol 65:1029-1035

Kim SJ, Ishikawa K, Hirai M, Shoda M (1995) Characteristics of a newly isolated fungus, Geotrichum candidum Dec 1, which decolorizes various dyes. J Ferment Bioeng 79:601-607

Koduri RS, Tien M (1995) Oxidation of guaiacol by lignin peroxidase. Role of veratryl alcohol. J Biol Chem 270:22254-22258

Liers C, Bobeth C, Pecyna M, Ullrich R, Hofrichter M (2010) DyP-like peroxidases of the jelly fungus Auricularia auricula-judae oxidize nonphenolic lignin model compounds and high-redox potential dyes. Appl Microbiol Biotechnol 85:1869-1879

Liers C, Aranda E, Strittmatter E, Piontek K, Plattner DA, Zorn H, Ullrich R, Hofrichter M (2013a) Phenol oxidation by DyP-type peroxidases in comparison to fungal and plant peroxidases. Enzym, J Mol Catal B

Liers C, Pecyna MJ, Kellner H, Worrich A, Zorn H, Steffen KT, Hofrichter M, Ullrich $R$ (2013b) Substrate oxidation by dye-decolorizing peroxidases (DyPs) from wood-and litter-degrading agaricomycetes compared to other fungal and plant heme-peroxidases. Appl Microbiol Biotechnol 97:5839-5849

Linde D, Coscolñas FJ (2014) Heterologous expression and physicochemical characterization of a fungal dye-decolorizing peroxidase from Auricularia auricula-judae. Protein Expr Purif 103:28-37

Linde D, Pogni R, Cañellas M, Lucas F, Guallar V, Baratto MC, Sinicropi A, SáezJiménez V, Coscolñas FJ, MartÁngel T (2015a) Catalytic surface radical in dye-decolorizing peroxidase: a computational, spectroscopic and sitedirected mutagenesis study. Biochem J 466:253-262
Linde D, Ruiz-Dueñas FJ, Fernández-Fueyo E, Guallar V, Hammel KE, Pogni R, Martínez ÁT (2015b) Basidiomycete DyPs: Genomic diversity, structuralfunctional aspects, reaction mechanism and environmental significance. Arch Biochem Biophys 574:66-74

Lundell TK, Mäkelä MR, Hildeén K (2010) Lignin-modifying enzymes in filamentous basidiomycetes_ecological, functional and phylogenetic review. J Basic Microbiol 50:5-20

Martínez ÁT (2002) Molecular biology and structure-function of lignindegrading heme peroxidases. Enzyme Microb Technol 30:425-444

McEldoon JP, Pokora AR, Dordick JS (1995) Lignin peroxidase-type activity of soybean peroxidase. Enzyme Microb Technol 17:359-365

Mester T, Field JA (1998) Characterization of a novel manganese peroxidaselignin peroxidase hybrid isozyme produced by Bjerkandera species strain BOS55 in the absence of manganese. J Biol Chem 273:15412-15417

Morgenstern I, Klopman S, Hibbett DS (2008) Molecular evolution and diversity of lignin degrading heme peroxidases in the Agaricomycetes. J Mol Evol 66:243-257

Peterson R, Nevalainen H (2012) Trichoderma reesei RUT-C30 —-thirty years of strain improvement. Microbiology 158:58-68

Poulos TL (2010) Thirty years of heme peroxidase structural biology. Arch Biochem Biophys 500:3-12

Pühse M, Szweda RT, Ma Y, Jeworrek C, Winter R, Zorn H (2009) Marasmius scorodonius extracellular dimeric peroxidase - exploring its temperature and pressure stability. Biochim Biophys Acta 1794:1091-1098

Rajarathnam S, Shashirekha MN, Bano Z (1998) Biodegradative and biosynthetic capacities of mushrooms: present and future strategies. Crit Rev Biotechnol 18:91-236

Renganathan V, Gold MH (1986) Spectral characterization of the oxidized states of lignin peroxidase, an extracellular heme enzyme from the white rot basidiomycete Phanerochaete chrysosporium. Biochemistry 25:1626-1631

Salvachúa D, Prieto A, Martínez ÁT, Martínez MJ (2013) Characterization of a novel dye-decolorizing peroxidase DyP-type enzyme from Irpex lacteus and its application in enzymatic hydrolysis of wheat straw. Appl Environ Microbiol 79:4316-4324

Saparrat MCN, Guillén F, Arambarri AM, Martínez ÁT (2002) Induction, isolation, and characterization of two laccases from the white rot basidiomycete Coriolopsis rigida. Appl Environ Microbiol 68:1534-1540

Scheibner M (2006) Identifizierung und Charakterisierung carotinoidabbauender Enzyme aus Basidiomyceten. Gottfried Wilhelm Leibniz Universität, Hannover

Scheibner M, Hülsdau B, Zelena K, Nimtz M, Boer L, Berger RG, Zorn H (2008) Novel peroxidases of Marasmius scorodonius degrade $\beta$-carotene. Appl Microbiol Biotechnol 77:1241-1250

Schüttmann I, Bouws H, Szweda RT, Suckow M, Czermak P, Zorn H (2014) Induction, characterization, and heterologous expression of a carotenoid degrading versatile peroxidase from Pleurotus sapidus. J Mol Catal B Enzym 103:79-84

Scotter MJ, Wilson LA, Appleton GP, Castle L (1998) Analysis of annatto (Bixa orellana) food coloring formulations. 1. Determination of coloring components and colored thermal degradation products by high-performance liquid chromatography with photodiode array detection. J Agric Food Chem 46:1031-1038

Strittmatter E, Liers C, Ullrich R, Wachter S, Hofrichter M, Plattner DA, Piontek K (2013) First crystal structure of a fungal high-redox potential dye-decolorizing peroxidase: substrate interaction sites and long-range electron transfer. J Biol Chem 288:4095-4102

Sugano Y (2009) DyP-type peroxidases comprise a novel heme peroxidase family. Cell Mol Life Sci 66:1387-1403

Sugano Y, Sasaki K, Shoda M (1999) cDNA cloning and genetic analysis of a novel decolorizing enzyme, peroxidase gene dyp from Geotrichum candidum Dec 1. J Biosci Bioeng 87:411-417

Sugano Y, Nakano R, Sasaki K, Shoda M (2000) Efficient heterologous expression in Aspergillus oryzae of a unique dye-decolorizing peroxidase, DyP, of Geotrichum candidum Dec 1. Appl Environ Microbiol 66:1754-1758

Sugano Y, Ishii Y, Shoda M (2004) Role of H164 in a unique dye decolorizing heme peroxidase DyP. Biochem Biophys Res Commun 322:126-132

Sugano Y, Matsushima Y, Shoda M (2006) Complete decolorization of the anthraquinone dye Reactive blue 5 by the concerted action of two peroxidases from Thanatephorus cucumeris Dec 1. Appl Microbiol Biotechnol 73:862-871 
Sugano Y, Muramatsu R, Ichiyanagi A, Sato T, Shoda M (2007) DyP, a unique dye-decolorizing peroxidase, represents a novel heme peroxidase family. Asp171 replaces the distal histidine of classical peroxidases. J Biol Chem 282:36652-36658

Szweda RT, Schmidt K, Zorn H (2013) Bleaching of colored whey and milk by a multiple-enzyme system. Eur Food Res Technol 237:377-384

Thomas PE, Ryan D, Levin W (1976) An improved staining procedure for the detection of the peroxidase activity of cytochrome P-450 on sodium dodecyl sulfate polyacrylamide gels. Anal Biochem 75:168-176

Wang Y, Vazquez-Duhalt R, Pickard MA (2002) Purification, characterization, and chemical modification of manganese peroxidase from Bjerkandera adusta UAMH 8258. Curr Microbiol 45:77-87

Ward G, Hadar Y, Bilkis I, Dosoretz CG (2003) Mechanistic features of lignin peroxidase-catalyzed oxidation of substituted phenols and 1,2-dimethoxyarenes. J Biol Chem 278:39726-39734

Welinder KG (1992) Superfamily of plant, fungal and bacterial peroxidases. Curr Opin Struct Biol 2:388-393

Yoshida T, Sugano Y (2015) A structural and functional perspective of DyP-type peroxidase family. Arch Biochem Biophys 574:49-55

Yoshida T, Tsuge H, Konno H, Hisabori T, Sugano Y (2011) The catalytic mechanism of dye-decolorizing peroxidase DyP may require the swinging movement of an aspartic acid residue. FEBS J 278:2387-2394
Yoshida T, Tsuge H, Hisabori T, Sugano Y (2012) Crystal structures of dye-decolorizing peroxidase with ascorbic acid and 2,6-dimethoxyphenol. FEBS Lett 586:4351-4356

Zámocký M, Furtmüller PG, Bellei M, Battistuzzi G, Stadlmann J, Vlasits J, Obinger C (2009) Intracellular catalase/peroxidase from the phytopathogenic rice blast fungus Magnaporthe grisea: expression analysis and biochemical characterization of the recombinant protein. Biochem J 418:443-451

Zámocký M, Hofbauer S, Schaffner I, Gasselhuber B, Nicolussi A, Soudi M, Pirker KF, Furtmüller PG, Obinger C (2015) Independent evolution of four heme peroxidase superfamilies. Arch Biochem Biophys 574:108-119

Zorn H, Langhoff S, Scheibner M, Berger RG (2003a) Cleavage of $\beta, \beta$-carotene to flavor compounds by fungi. Appl Microbiol Biotechnol 62:331-336

Zorn H, Langhoff S, Scheibner M, Nimtz M, Berger RG (2003b) A peroxidase from Lepista irina cleaves $\beta$, $\beta$-carotene to flavor compounds. Biol Chem 384:1049-1056

Zorn H, Bouws H, Takenberg M, Nimtz M, Getzlaff R, Breithaupt DE, Berger RG (2005) An extracellular carboxylesterase from the basidiomycete Pleurotus sapidus hydrolyses xanthophyll esters. Biol Chem 386:435-440

\section{Submit your manuscript to a SpringerOpen ${ }^{\circ}$ journal and benefit from:}

- Convenient online submission

- Rigorous peer review

- Open access: articles freely available online

- High visibility within the field

Retaining the copyright to your article

Submit your next manuscript at $\boldsymbol{\nabla}$ springeropen.com 